\title{
1. INTRODUCTION, OBJECTIVES, AND PRINCIPAL RESULTS, LEG 112, PERU CONTINENTAL MARGIN ${ }^{1}$
}

\author{
Shipboard Scientific Party ${ }^{2}$
}

The Andean Continental Margin is a prominent boundary in both global plate-tectonic framework and global oceanic circulation pattern. Two processes, plate subduction and coastal upwelling, shaped this margin and its sediments since Eocene time. Studies of these two processes off South America increased our general knowledge of subducting plate boundaries and the dynamics of coastal upwelling.

Although seismologists have studied the Andean Continental Margin since the concept of the Benioff Zone was developed, the tectonic structure of the convergent Andean margin has not conformed to classic plate-tectonic concepts. Several authors noted the lack of pervasive compressional deformation and an extensive accretionary complex. In addition, they noted that the front of the Mesozoic margin was missing (Rutland, 1971; Scholl et al., 1970). Investigations during the Nazca Plate Project indicated that the continental crust extended to at least the edge of the shelf and that sediment had accreted along the lower continental slope (Kulm et al., 1985; Hussong and Wipperman, 1981). Subsequently, reprocessing of multichannel seismic records decreased the uncertainty about the structure be-

\footnotetext{
${ }^{1}$ Suess, E., von Huene, R., et al., 1988. Proc. ODP, Init. Repts., 112: College Station, TX (Ocean Drilling Program).

2 Erwin Suess (Co-Chief Scientist), Oregon State University, College of Oceanography, Corvallis, OR 97331; Roland von Huene (Co-Chief Scientist), U.S. Geological Survey, Branch of Pacific Marine Geology, 345 Middlefield Rd. M/S 999, Menlo Park, CA 94025; Kay-Christian Emeis (ODP Staff Scientist), Ocean Drilling Program, Texas A\&M University, College Station, TX 77843; Jacques Bourgois, Département de Géotectonique, Université Pierre et Marie Curie, 4 Place Jussieu, 75230 Paris Cedex 05, France; José del C. Cruzado Castañeda, Petroleos del Peru S. A., Paseo de la Republica 3361, San Isidro, Lima, Peru; Patrick De Wever, CNRS, Laboratoire de Stratigraphie, Université Pierre et Marie Curie, 4 Place Jussieu, 75230 Paris Cedex 05, France; Geoffrey Eglinton, University of Bristol, School of Chemistry, Cantock's Close, Bristol BS8 1TS, England; Robert Garrison, University of California, Earth Sciences, Applied Sciences Building, Santa Cruz, CA 95064; Matt Greenberg, Lamont-Doherty Geological Observatory, Columbia University, Palisades, NY 10964; Elard Herrera Paz, Petroleos del Peru, S. A., Paseo de la Republica 3361, San Isidro, Lima, Peru; Phillip Hill, Atlantic Geoscience Centre, Bedford Institute of Oceanography, Box 1006, Dartmouth, Nova Scotia B2Y 4A2, Canada; Masako Ibaraki, Geoscience Institute, Faculty of Science, Shizuoka University, Shizuoka 422, Japan; Miriam Kastner, Scripps Institution of Oceanography, SVH, A-102, La Jolla, CA 92093; Alan E. S. Kemp, Department of Oceanography, The University, Southampton SO9 $5 \mathrm{NH}$, England; Keith Kvenvolden, U.S. Geological Survey, Branch of Pacific Marine Geology, 345 Middlefield Rd., M/S 999, Menlo Park, CA 94025; Robert Langridge, Department of Geological Sciences, Queen's University at Kingston, Ontario K7L 3A2, Canada; Nancy Lindsley-Griffin, University of Nebraska, Department of Geology, 214 Bessey Hall, Lincoln, NE 68588-0340; Janice Marsters, Department of Oceanography, Dalhousie University, Halifax, Nova Scotia B3H 4J1, Canada; Erlend Martini, Geologisch-Paläontologisches Institut der Universität Frankfurt, Senckenberg-Anlage 32-34, D-6000, Frankfurt/Main, Federal Republic of Germany; Robert McCabe, Department of Geophysics, Texas A\&M University, College Station, TX 77843; Leonidas Ocola, Laboratorio Central, Instituto Geofisico del Peru, Lima, Peru; Johanna Resig, Department of Geology and Geophysics, University of Hawaii, Honolulu, HI 96822; Agapito Wilfredo Sanchez Fernandez, Instituto Geologico Minero y Metalurgico, Pablo Bermudez 211, Lima, Peru; Hans-Joachim Schrader, College of Oceanography, Oregon State University, Corvallis, OR 97331 (currently at Department of Geology, University of Bergen, N-5000 Bergen, Norway); Todd Thornburg, College of Oceanography, Oregon State University, Corvallis, OR 97331; Gerold Wefer, Universität Bremen, Fachbereich Geowissenschaften, Postfach 330 440, D-2800 Bremen 33, Federal Republic of Germany; Makoto Yamano, Earthquake Research Institute, University of Tokyo, Bunkyo-ku, Tokyo 113, Japan.
}

tween the continental crust and the accretionary complex to the mid- and lower-slope areas (von Huene et al., 1985; Kulm et al., 1987; Miller et al., 1986). Thus, the tectonic objectives of Leg 112 were (1) to test hypotheses inferred from studying geophysical data and conventional sampling along the Peru margin about the seaward extent of the continental crust, (2) to study the nature of the margin's junction with the accretionary complex, and to relate the tectonic history of the continental margin to the plate convergence of the oceanic crust.

The record of paleoenvironmental changes and the diagenetic process of the forearc basins are linked closely to the tectonic history of the margin. Initiation of the eastern Pacific boundary current circulation and the associated wind systemsa process that established the coastal upwelling regime during Miocene time-occurred during the subduction of the modern Nazca Plate beneath the South American craton, leading to the development of forearc basins. Sedimentation in these basins (which form a series of elongated, mostly structural depressions on the shelf and upper slope off Peru) reflects vertical movements of the Andean margin basement and records the detailed oceanographic history of one of the best-developed coastal upwelling regimes (Suess and Thiede, 1983; Thiede and Suess; 1983; Fig. 1).

Both the rapid vertical motion of forearc basins and the influx of biogenic matter from coastal upwelling mixed with terrigenous material generate an extreme range of chemical and sedimentological conditions that affect diagenesis. These conditions are dominated by microbially mediated decomposition of organic matter in response to changing rates of sediment accumulation and basin subsidence. This interplay between incoming rates of material and tectonic history leads to widespread diagenetic dolomitization in the sediments of forearc basins by either microbial sulfate reduction or by fermentation (Suess et al., 1987; Kulm et al., 1984). Leg 112 addressed this interplay between tectonic and oceanographic processes and their role in sedimentation and diagenesis of the forearc basins. The paleoenvironmental history is recorded in the sediment sequences drilled in the forearc basins of Salaverry, Lima, Yaquina, Trujillo, and West Pisco and on the adjacent continental slope.

\section{OBJECTIVES}

Discovering the amplitude of vertical tectonic movement of these basins and the timing of these events were prime objectives. In addition, we wished to date the onset of coastal upwelling and to determine the response of the upwelling circulation regime to tectonic and climatic forcing. With these overall goals, our specific objectives were as follows:

1. To reconstruct the uplift and subsidence history of the forearc area while relating these vertical movements to tectonic accretion and the erosion of older strata at the Pacific margin of the South American craton.

2. To study the nature and age of the transition zone that lies between the lower-slope accretionary complex and the metamorphic block of continental affinity. 
A

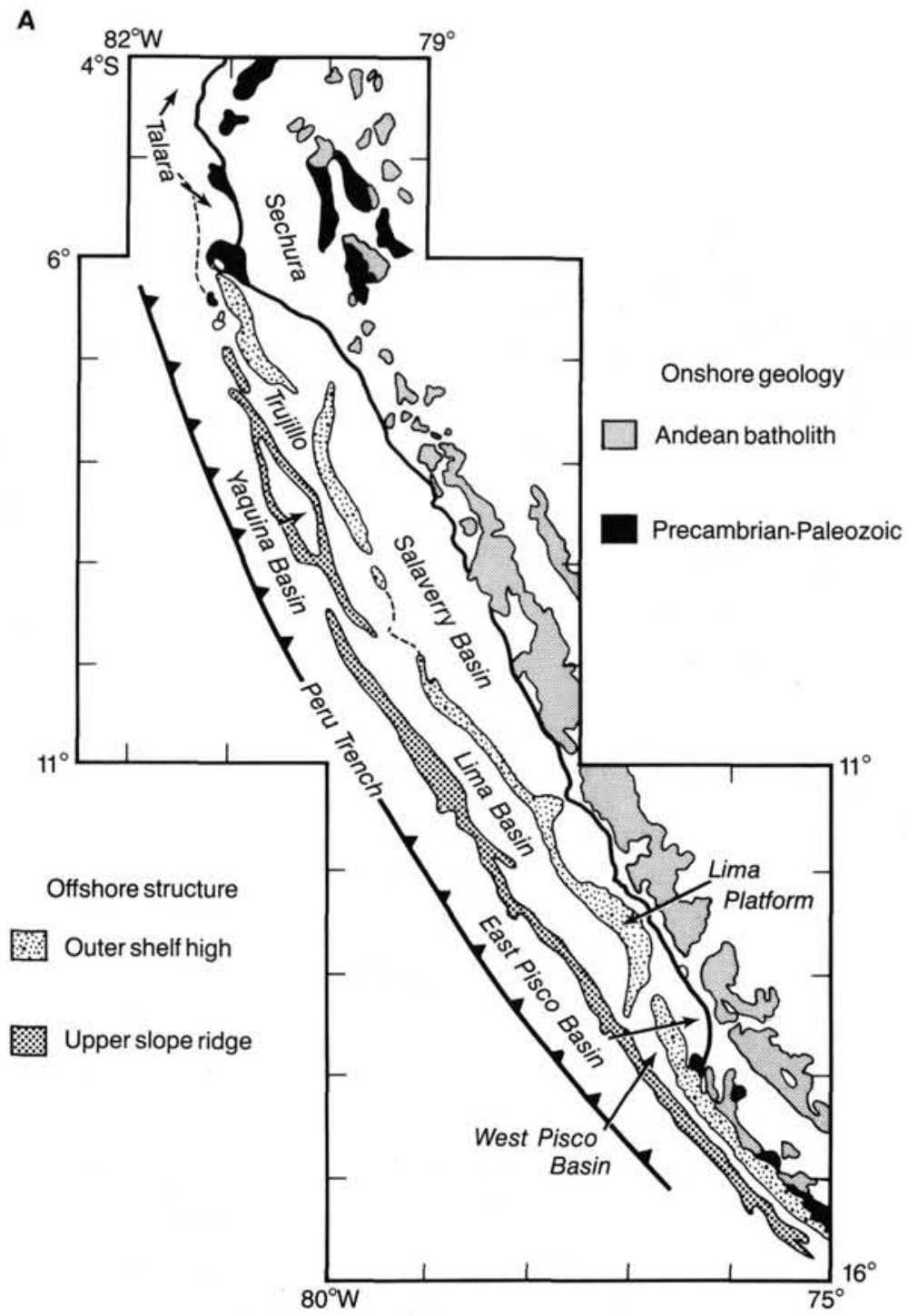

B

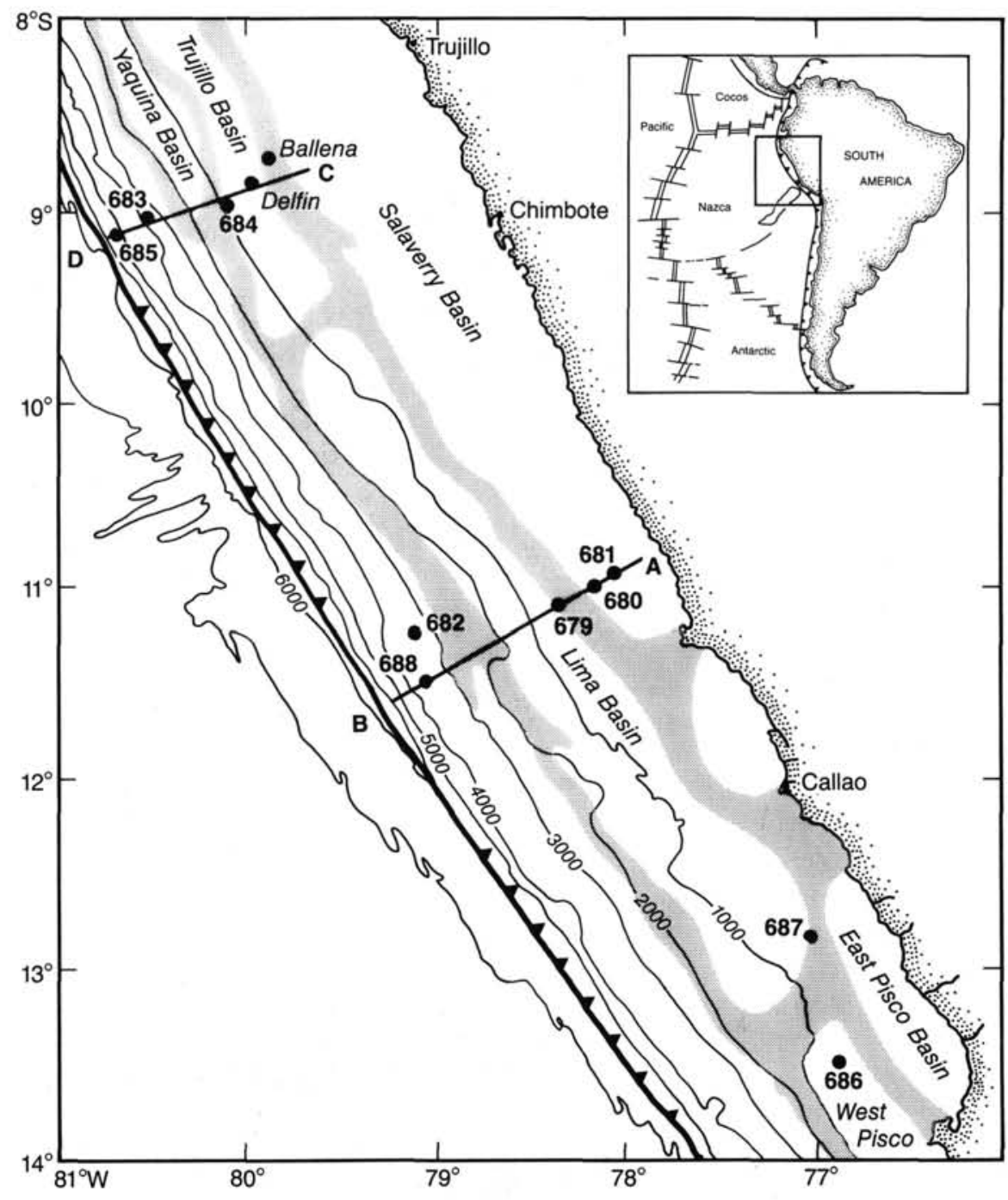

Figure 1. A) Major forearc basins along the Peru Continental Margin, onshore and offshore structures that control the distribution of these sedimentary basins; B) Locations of transects in the northern (C-D) and southern (A-B) areas of investigation, bathymetry, and location of sites drilled during leg 112; modified from Thornburg and Kulm (1981). Bathymetry in meters. 
3. To investigate the age of the metamorphic basement underlying the outer Andean margin, as well as pressure and temperature conditions of metamorphism through time.

4. To document accretion and erosion of the continental margin as a response to the tectonic history of Nazca Plate subduction under South America.

5. To reconstruct the paleoceanographic conditions of the upper-slope basin deposits in terms of the response of biological and sedimentary systems to fluctuations in intensity and the source of upwelling waters.

6. To quantify biogenic and clastic fluxes for evaluating interactions among sea level, climate, and oceanic circulation.

7. To understand the conditions leading to the formation of dolomites, phosphorites, and cherts in shelf and upper-slope basin deposits.

8. To determine whether microbial activity persists to depths of around 100 meters below seafloor (mbsf), thereby affecting the diagenetic environment in organic carbon-rich sediments.

With these goals in mind, the scientists on board JOIDES Resolution departed Callao, Peru on 30 October 1986. During the 51 days of operations, 27 holes were drilled at 10 sites to meet these scientific objectives. A total of $6754 \mathrm{~m}$ of sediment was penetrated, of which $4701.3 \mathrm{~m}$ was cored and $2578 \mathrm{~m}$ was recovered (Table 1). The ship returned to Callao on 19 December 1986.

\section{CONVERGENT MARGIN TECTONICS}

\section{Northern Corridor}

\section{Regional Setting}

During Leg 112, drilling was concentrated in two corridors previously surveyed, using geophysical techniques and sampling by conventional means. The northern corridor (near $9^{\circ} \mathrm{S}$ off central Peru) was cored at three ODP sites $(684,683$, and 685 ; Fig. 1) to constrain seismic interpretations. These sites are seaward of two industry drill holes (Delfin and Ballena) and landward of two DSDP sites (320 and 321) on the Nazca Plate. Morphologies of the wide north-central continental shelf and the slope are typical of the Andean margin. This shelf is underlain by the coastal Salaverry and by the outer-shelf/upper-slope Trujillo basins (Thornburg, 1985). The upper continental slope is underlain by the Yaquina Basin. The upper-slope morphology ends at water depths between 3000 and $4000 \mathrm{~m}$ along a locally steepened, scarplike feature above the midslope terrace- a feature of broad regional extent (Prince et al., 1980; Bourgois et al., 1986). Below this terrace, the lower slope descends at a relatively constant dip to the flat floor of the Peru Trench. Seaward of the trench, the surveyed corridor includes an 850-m-high ridge subparallel to the trench axis, just beginning subduction. Consequently, the trench floor is locally constricted by this collision (Bourgois et al., 1986).

Table 1. Sites drilled during Leg 112.

\begin{tabular}{|c|c|c|c|c|c|c|}
\hline \multirow[b]{2}{*}{ Site } & \multicolumn{2}{|c|}{ Position } & \multirow{2}{*}{$\begin{array}{l}\text { Water depth } \\
\text { (mbsl) }\end{array}$} & \multirow{2}{*}{$\begin{array}{l}\text { Sediment } \\
\text { drilled } \\
\text { (mbsf) }\end{array}$} & \multirow{2}{*}{$\begin{array}{l}\text { Recovery } \\
(\%)\end{array}$} & \multirow{2}{*}{$\begin{array}{l}\text { Age of oldest } \\
\text { sediment }\end{array}$} \\
\hline & Latitude & Longitude & & & & \\
\hline \multicolumn{7}{|l|}{$112-679$} \\
\hline A & $11^{\circ} 03.52^{\prime} \mathrm{S}$ & $78^{\circ} 15.92^{\prime} \mathrm{W}$ & 439.5 & 7.0 & 100.0 & Holocene \\
\hline B & $11^{\circ} 03.80^{\prime} \mathrm{S}$ & $78^{\circ} 16.34^{\prime} \mathrm{W}$ & 450.5 & 107.2 & 96.1 & Pliocene \\
\hline C & $11^{\circ} 03.81^{\prime} \mathrm{S}$ & $78^{\circ} 16.33^{\prime} \mathrm{W}$ & 450.5 & 75.5 & 92.4 & Pliocene \\
\hline D & $11^{\circ} 03.83^{\prime} \mathrm{S}$ & $78^{\circ} 16.33^{\prime} \mathrm{W}$ & 439.5 & 245.4 & 47.1 & late Miocene \\
\hline $\mathbf{E}$ & $11^{\circ} 03.78^{\prime} \mathrm{S}$ & $78^{\circ} 16.34^{\prime} \mathrm{W}$ & 462.0 & $a_{359.3}$ & 31.8 & middle Miocene \\
\hline \multicolumn{7}{|l|}{680} \\
\hline A & $11^{\circ} 03.90^{\prime} \mathrm{S}$ & $78^{\circ} 04.67^{\prime} \mathrm{W}$ & 252.5 & 93.8 & 87.0 & Pleistocene \\
\hline B & $11^{\circ} 03.90^{\prime} \mathrm{S}$ & $78^{\circ} 04.67^{\prime} \mathrm{W}$ & 252.5 & 195.5 & 50.4 & early Pliocene \\
\hline C & $11^{\circ} 03.90^{\prime} \mathrm{S}$ & $78^{\circ} 04.67^{\prime} \mathrm{W}$ & 252.5 & 34.3 & 102.0 & Pleistocene \\
\hline \multicolumn{7}{|l|}{681} \\
\hline A & $10^{\circ} 58.60^{\prime} \mathrm{S}$ & $77^{\circ} 57.46^{\prime} \mathrm{W}$ & 150.5 & 187.0 & 60.0 & Pleistocene \\
\hline B & $10^{\circ} 58.60^{\prime} \mathrm{S}$ & $77^{\circ} 57.46^{\prime} \mathrm{W}$ & 150.5 & 143.5 & 67.8 & Miocene(?) \\
\hline C & $10^{\circ} 58.60^{\prime} \mathrm{S}$ & $77^{\circ} 57.46^{\prime} \mathrm{W}$ & 150.5 & 91.4 & 98.7 & Pleistocene \\
\hline 682 & -2.00 & & & & & \\
\hline$\underset{683}{A}$ & $11^{\circ} 15.99^{\prime} \mathrm{S}$ & $79^{\circ} 03.73^{\prime} \mathrm{W}$ & 3788.5 & 436.7 & 29.1 & Eocene \\
\hline A & $09^{\circ} 01.69^{\prime} \mathrm{S}$ & $80^{\circ} 24.40^{\prime} \mathrm{W}$ & 3071.8 & 419.2 & 52.2 & middle Miocene \\
\hline B & $09^{\circ} 01.59^{\prime} \mathrm{S}$ & $80^{\circ} 24.26^{\prime} \mathrm{W}$ & 3071.5 & $a_{488.0}$ & 35.7 & middle Eocene \\
\hline \multicolumn{7}{|l|}{684} \\
\hline A & $08^{\circ} 59.59^{\prime} \mathrm{S}$ & $79^{\circ} 54.35^{\prime} \mathrm{W}$ & 426.0 & 136.1 & 53.2 & middle Miocene \\
\hline B & $08^{\circ} 59.59^{\prime} \mathrm{S}$ & $79^{\circ} 54.35^{\prime} \mathrm{W}$ & 426.5 & 55.0 & 67.6 & Pliocene \\
\hline C & $08^{\circ} 59.59^{\prime} \mathrm{S}$ & $79^{\circ} 54.35^{\prime} \mathrm{W}$ & 426.5 & 115.0 & 48.8 & middle Miocene \\
\hline \multicolumn{7}{|r|}{ 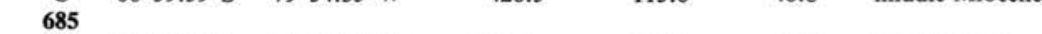 } \\
\hline$\underset{686}{A}$ & $09^{\circ} 06.78^{\prime} \mathrm{S}$ & $80^{\circ} 35.01^{\prime} \mathrm{W}$ & 5070.8 & 468.6 & 59.4 & late Miocene \\
\hline A & $13^{\circ} 28.81^{\prime} \mathrm{S}$ & $76^{\circ} 53.49^{\prime} \mathrm{W}$ & 446.8 & 205.7 & 88.3 & Pleistocene \\
\hline B & $13^{\circ} 28.81^{\prime} \mathrm{S}$ & $76^{\circ} 53.49^{\prime} \mathrm{W}$ & 446.8 & 303.0 & 74.4 & Pleistocene \\
\hline \multicolumn{7}{|l|}{687} \\
\hline A & $12^{\circ} 51.78^{\prime} \mathrm{S}$ & $76^{\circ} 59.43^{\prime} \mathrm{W}$ & 306.8 & 207.0 & 52.3 & Pliocene \\
\hline B & $12^{\circ} 51.78^{\prime} \mathrm{S}$ & $76^{\circ} 59.43^{\prime} \mathrm{W}$ & 306.8 & 195.3 & 44.7 & Pliocene \\
\hline \multicolumn{7}{|l|}{688} \\
\hline A & $11^{\circ} 32.26^{\prime} \mathrm{S}$ & $78^{\circ} 56.57^{\prime} \mathrm{W}$ & 3819.8 & 350.3 & 70.0 & Pliocene(?) \\
\hline B & $11^{\circ} 32.26^{\prime} \mathrm{S}$ & $78^{\circ} 56.57^{\prime} \mathrm{W}$ & 3819.8 & $a_{360.0}$ & 0.0 & \\
\hline C & $11^{\circ} 32.26^{\prime} \mathrm{S}$ & $78^{\circ} 56.57^{\prime} \mathrm{W}$ & 3819.8 & $a_{359.8}$ & 12.0 & Pleistocene \\
\hline D & $11^{\circ} 32.26^{\prime} \mathrm{S}$ & $78^{\circ} 56.57^{\prime} \mathrm{W}$ & 3819.8 & $a_{345.0}$ & 0.0 & \\
\hline E & $11^{\circ} 32.28^{\prime} \mathrm{S}$ & $78^{\circ} 56.65^{\prime} \mathrm{W}$ & 3825.8 & ${ }^{\mathrm{a}} 769.5$ & 35.4 & Eocene \\
\hline
\end{tabular}

a Indicates that part of the hole was washed. The washed intervals were (1) Hole 679E, 0-245 mbsf; (2) Hole 683B, 0-402.5 mbsf; (3) Hole 688B, 0-360 mbsf; (4) Hole 688C, 0-350.3 mbsf; (5) Hole $688 \mathrm{D}, 0-345$ mbsf; and (6) Hole 688E, 0-350 mbsf. 
This morphology reflects a range of tectonic structural transition between rapid deformation along the trench to relative stability in the coastal area. The shelf is underlain principally by the coastal Salaverry Basin, a little fault-bounded syncline. The adjacent Trujillo Basin, which straddles the shelf edge, is cut by many small faults of limited displacement (Thornburg, 1985). Samples of the landward flank and center of the basin were obtained from the Ballena and Delfin exploration drill holes (Fig. 2), revealing an Eocene to upper Miocene continental-shelf sedimentary sequence above an erosional surface on Paleozoic metamorphic basement (Kulm et al, 1985; H. Schrader and J. Cruzado, pers. commun., 1987). A low basement ridge that crops out locally on the upper slope separates the Trujillo and Yaquina basins. The Yaquina Basin, with a depocenter in the middle of the upper slope, is cut by numerous normal faults on its landward flank (von Huene et al., 1985) that break the seafloor into a zone of anastomosing scarps observed in SeaMARC II images (Hussong et al., 1985b).

The midslope terrace is associated with a major tectonic boundary near the front of the Peruvian margin that juxtaposes crystalline continental crust against an accretionary complex. Although poor images of this structure boundary occur in all midslope seismic-reflection data (von Huene et al., 1985), the terrace is tectonically significant because the disparate tectonic environments on either side indicate that a large segment of transitional crust is now missing (Fig. 2). Evidence about the accretionary origin of sediment at the front of the margin is indicated by thrust packets adjacent to the trench floor and by the numerous landward-dipping reflections beneath the lower slope. The subduction zone is clearly marked in seismic records by thick stratiform sequences (Kulm et al., 1981; von Huene et al., 1985) that represent subducted trench sediment. The Peru Trench is filled with turbidites about $1 \mathrm{~cm}$ thick (Kulm et al., 1981; Bourgois et al., 1986). Below this trench is a layer of hemipelagic and pelagic sediment above the igneous oceanic crust.

Before Leg 112, studies of the geophysical data and reports of industrial drill holes indicated that the same continental crust exposed along the coast on offshore islands (dredged from outcrops and drilled at the edge of the shelf) could be extrapolated geophysically across the upper slope to the midslope terrace. This basement is unconformably overlain by sediment of Eocene and younger age deposited following a period of orogeny and uplift during the late Paleocene and Eocene, when vast areas of the Peruvian margin were subaerially exposed (summarized in Thornburg, 1985). Because the unconformity at the base of the Eocene was once subaerial, the crust has since sub-

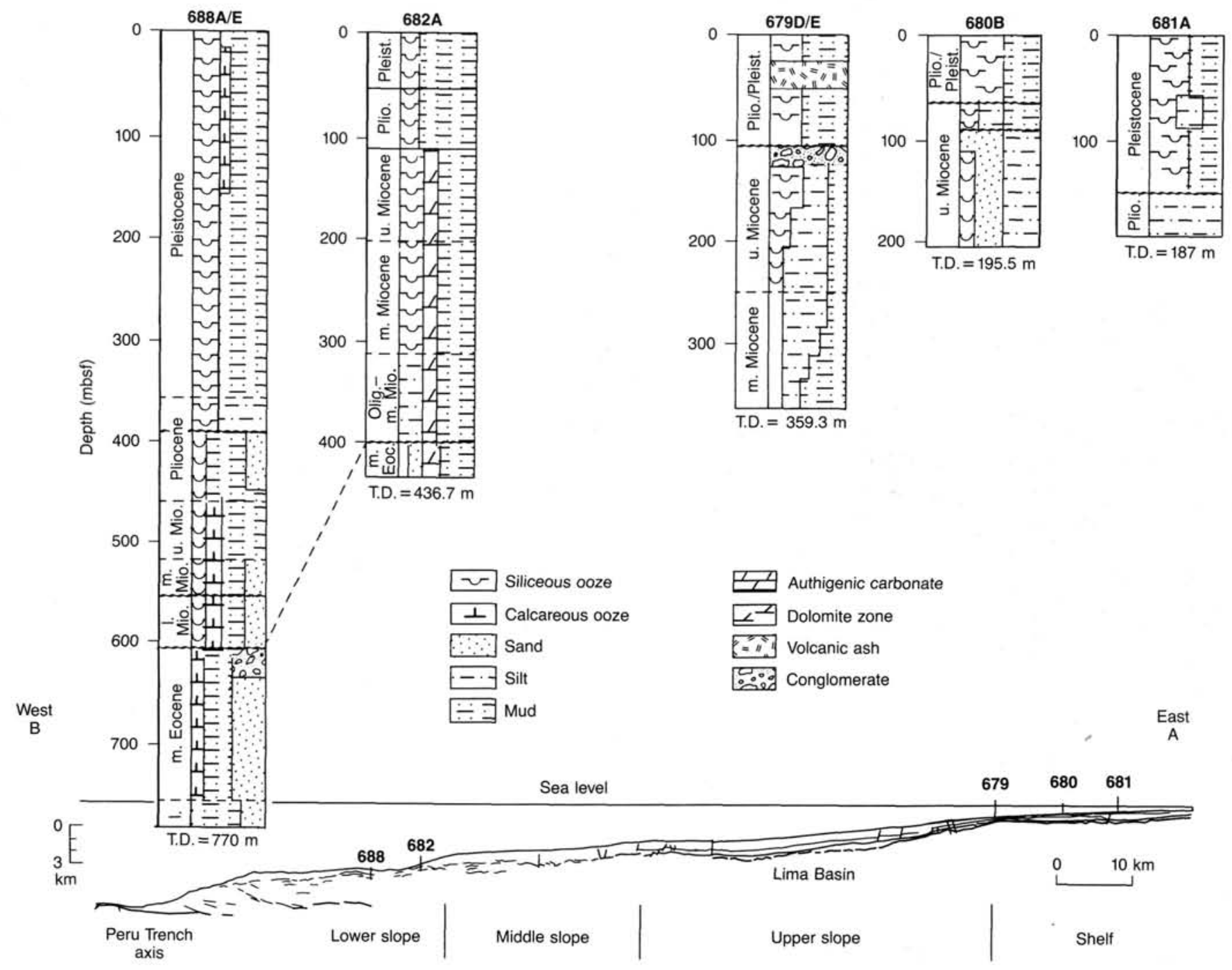

Figure 2. Simplified structural transect based on seismic survey and results of Leg 112 across the Peruvian margin at $9^{\circ} \mathrm{S}$. Included are results from industry holes, Ballena and Delfin. T.D. = total penetration depth. 
sided. Objectives at Site 683 , at the distal edge of the Yaquina Basin, included verification that continental crust extends this far seaward with considerable subsidence. We included this objective with those of a site across the tectonic boundary separating the two types of crust. The objectives at Site 685 , just below the midslope terrace, included verifying of accretion and establishing the time when this process started. Site 684, at the edge of the shelf, was drilled to obtain a Quaternary paleoceanographic record. Middle Miocene sediment was recovered at depth at this site, thus providing a stratigraphic tie to the industry holes of Delfin and Ballena in the Trujillo Basin (Fig. 2).

\section{Tectonic and Stratigraphic Histories}

Time and stratigraphic histories revealed by drilling along the northern corridor provide a tectonic framework for the northcentral Peruvian margin since Eocene time. Rocks of Eocene age were drilled at Site 683 and also were recovered in clasts of a sedimentary breccia at Site 685 . The Eocene section of seismic record CDP-2 can be followed from Site 683 landward across the upper slope to the basement ridge separating the Yaquina and Trujillo basins (Fig. 2). Across the ridge, this section is thick in the Delfin drill hole, but is absent on the basement ridge penetrated at the Ballena hole. Eocene sediments do not extend shoreward beneath the Salaverry Basin. Distribution of these Eocene sediments was controlled by (1) the subaerial basement topography with sediment transport from the east, (2) trapping of the coarse fraction in the Trujillo Basin, and (3) the restricted outlet over a sill along the seaward basin flank. The muds that spilled over the sill were distributed uniformly over a gentle slope without much topography forming the floor of Yaquina Basin. After Eocene time, these basins subsided; by the end of the middle Eocene, Site 683 was probably located on an upper slope. The long hiatus between Eocene and middle Miocene time extends across the Yaquina Basin. This hiatus is a regional feature across the Salaverry Basin and on the adjacent land (J. Cruzado, pers. commun., 1986). After the hiatus, middle Miocene sedimentation resulted in another sequence of uniformly thick ( $>200 \mathrm{~m}$ ) mudstones across the Yaquina Basin. A similar thickness was deposited in the Trujillo Basin. The Miocene benthic foraminifers at Site 683 indicate a depth in the lower bathyal zone; those in sediments at Site 684 indicate a middle and upper bathyal zone. These relative depths and the uniform thickness of the middle Miocene sediments suggest a gentle slope between the sites.

At the front of the Peru margin (Site 685), the oldest accreted sediment was deposited during the late Miocene; the late Miocene also is represented by a break in sedimentation on the upper slope. Sedimentary breccias in the accreted sequence contain components of Eocene, early Miocene, and middle to late Miocene age. They show that an unstable slope exposed a sediment sequence of this age during late Miocene time that was eroded. The Miocene sediment was accreted sometime during a period of $4.3 \mathrm{~m}$.y., when deposition started and before the discordantly overlying slope deposits accumulated.

The Pliocene and Quaternary sediments are thick in the Salaverry Basin, relatively thin at the edge of the Trujillo Basin on the shelf, and thickest on the continental slope in the Yaquina Basin (Fig. 2). Following sedimentation in the Miocene, sediment ponded in the coastal Salaverry Basin, but was eroded from the section of the Trujillo Basin at the edge of the shelf. Much of the sediment eroded from the shelf edge was deposited in the Yaquina Basin on the upper slope. Observations from Leg 112 cores and the exhumed basement outcrops along the ridge between the Trujillo and Yaquina basins (Thornburg, 1985; Thornburg and Kulm, 1981) indicate uplift of the ridge into the zone affected by fluctuating high- and low-energy environments from variations in sea level.
Observations from drilling and geophysical surveys in the northern corridor indicate the following general tectonic history. During early Eocene time, the Peruvian continental shelf extended far seaward of its present coast, at least to the position of today's midslope area. During the middle Eocene, the shelf subsided, while sediment filled much of the formerly subaerial Trujillo Basin, overtopped the silled margin, and spread into today's Yaquina Basin. An Oligocene hiatus on the margin, which is widespread throughout the Peruvian coastal area, corresponds to an eastward shift of the magmatic arc and volcanism to the Western Cordillera of the Andes. This must have been caused by a shift in the position or configuration of the subduction zone. The base of the upper slope subsided to lower bathyal water depths by middle Miocene time. Thus, the seaward edge of the continent subsided at least $2 \mathrm{~km}$ during the early stages of the uplift of the modern Andes. This subsidence suggests a subduction zone dominated by subcrustal tectonic erosion rather than accretion. Accretion began during late Miocene time at the latitude of the northern corridor.

What then were the regional geologic and plate-tectonic conditions at the time ( $\sim 6$ to $7 \mathrm{Ma})$ the Andean margin changed from a nonaccretionary to an accretionary margin? The Miocene was a time of increased sedimentation, as seen from Leg 112 data. The rate of plate convergence was exceptionally rapid between 8 and $5 \mathrm{Ma}$ (Cande, 1985). The Nazca Ridge was subducted at the latitude of the northern corridor $\left(9^{\circ} \mathrm{S}\right)$ between 8.8 Ma (Nur and Ben-Avraham, 1981) and $7 \mathrm{Ma}$ (Cande, 1985). We speculate that an increased quantity of sediment on the slope and in the trench axis, the increased rate of plate convergence, and the tectonic disruption caused by subduction of the Nazca Ridge may all have contributed to the change from a nonaccretionary to an accretionary convergent margin.

\section{Southern Corridor}

\section{Regional Setting}

During the Nazca Plate Project, an area at $11^{\circ} \mathrm{S}$ across the Lima Basin was studied extensively (Hussong and Wipperman, 1981; Kulm et al., 1981); a subsequent study selected drill sites for Leg 112 (Hussong et al., 1985b). The geophysical survey that included SeaMARC II and multichannel seismic techniques centered around multichannel seismic record CDP-1, with sampling that included targets identified from SeaMARC II images. Just before Leg 112, a Seabeam and geophysical study was conducted from the J. Charcot (Bourgois et al., 1986). CDP-1 was reprocessed by stacking twice the number of channels used originally and by migration (von Huene and Miller, this volume.). Although the sites selected for drilling were on three different seismic lines, they were projected into a generalized interpretation of CDP-1 that characterized the area (Fig. 3).

The morphology of the southern area differs from the northern corridor in that it has a narrower shelf and three wide terraces on the upper, middle, and lower slopes, respectively (Fig. 3). Beneath each terrace is a sediment-filled basin. The coastal Salaverry Basin is common to both the northern and southern corridors. The place of the outer-shelf/upper-slope Trujillo Ba$\sin$ in the north is taken by the upper- to middle-slope Lima Basin in the south. The upper and middle slopes are divided by a buried ridge (Fig. 3). The lower-slope terrace is perched above a planar lower slope that descends at a $12^{\circ}$ angle to the trench axis. The SeaMARC II image of the southern area shows outcrops of sedimentary strata and normal faults on the ridges separating the terraces. On the lower slope, a series of regularly spaced linear ridges is parallel to the trench (Hussong et al., 1985a). Morphology of the southern area is distinct from that of the northern area in two ways: (1) the greater depth of the Lima Basin compared with that of the Trujillo Basin and (2) the 


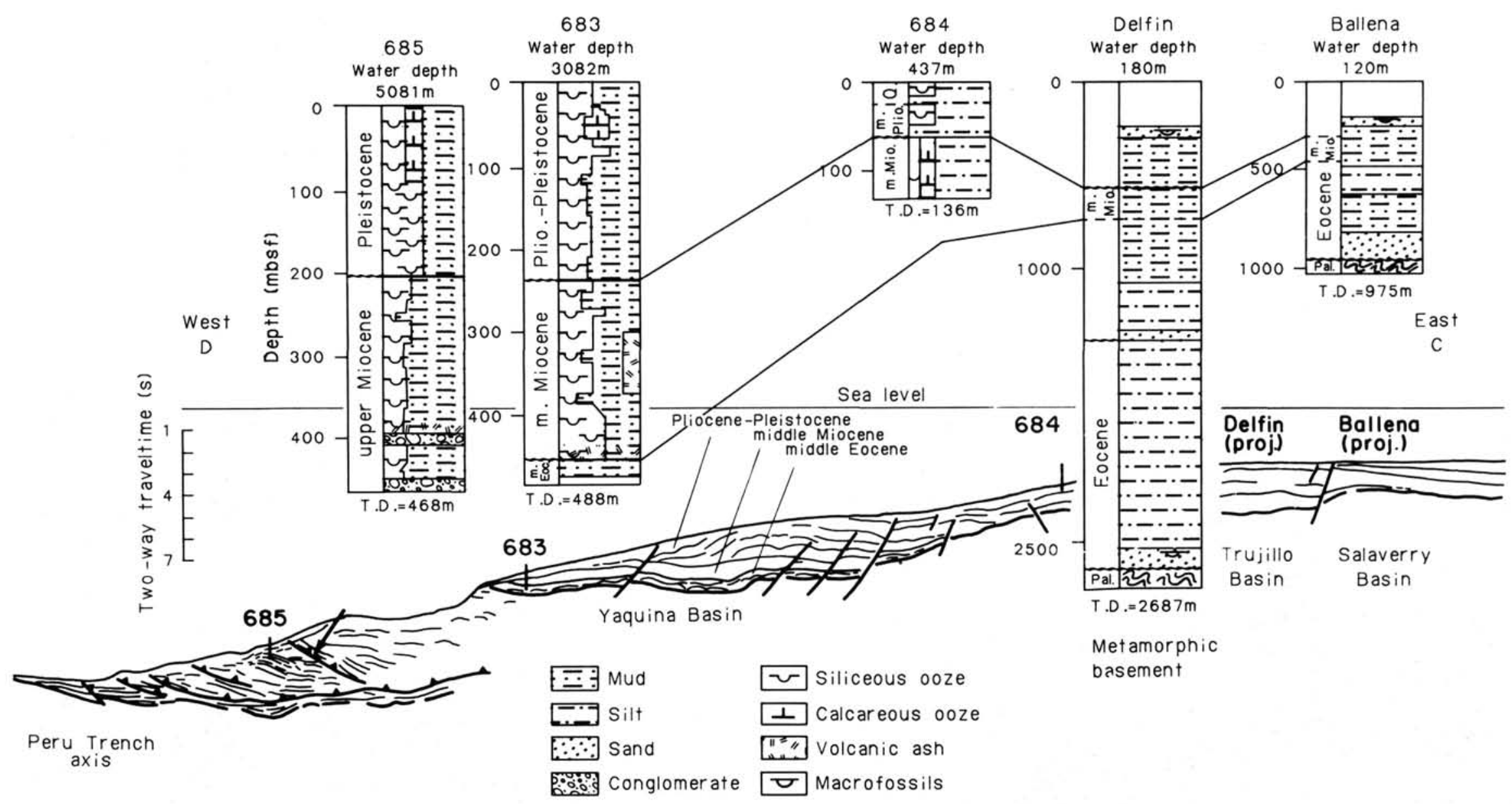

Figure 3. Simplified structural transect, based on seismic survey (Thornburg, 1985) and results of Leg 112 across the Peruvian margin at $11^{\circ} 30^{\prime} \mathrm{S}$. 
adjoining middle slope ridge and terrace, which do not occur in the northern corridor.

The margin is constructed of normally faulted ridges that form barriers between basins (Thornburg, 1985), but the lower slope is probably disrupted by imbricate thrust faults spaced about $1 \mathrm{~km}$ apart (Hussong and Wipperman, 1981; Hussong et al., 1985a). Lima Basin contains about $1200 \mathrm{~m}$ of sediment of Miocene and younger age at its depocenter (Kulm et al., 1981). Benthic foraminifer assemblages in dredged sediments indicate a subsidence rate between 275 and $500 \mathrm{~m} / \mathrm{m}$.y. for the Lima Basin (Kulm et al., 1981; Kulm et al., 1984). Small, normal faults are common on both the landward and the seaward flanks of the Lima Basin. Beneath the floor of the basin, seismic velocities are similar to those of continental crystalline basement onshore (Hussong and Wipperman, 1981).

The seismic reflection data recorded during the site survey (Hussong et al., 1985b) reveal a profound unconformity beneath the Lima Basin. In reprocessed seismic records CDP-1 and Shell 1017 (von Huene and Miller, this volume.), the unconformity truncates steeply dipping beds. Reconstruction of the pre-unconformity structure indicates removal of possibly as much as $750 \mathrm{~m}$ of sediment. In CDP-1, this erosion is confined to a segment $60 \mathrm{~km}$ wide beneath the upper slope and terrace, where the sediment fill of the Lima Basin is now thickest.

\section{Tectonic and Stratigraphic Histories}

The distribution of sites along the southern corridor provides stratigraphic control at both the seaward (Sites 682 and 688) and the landward ends (Site 679) (Fig. 1). The lithology and biostratigraphy of Eocene rocks drilled at the seaward end of the corridor are similar to the onshore stratigraphy of the Eocene Chira, Verdun, and Talara formations. The benthic foraminifer assemblages contain upper bathyal to shelf-dwelling faunas, megafossils, and lithologies that indicate proximity of shallow high-energy marine environments, which suggests deposition on a broad shelf. The top of this Eocene facies also was penetrated at Site 683 (in the northern corridor) and similar Eocene rocks were dredged during site surveys. Above the Eocene is a major Oligocene hiatus that is as pronounced offshore as it is onshore (Fig. 4). The stratigraphic similarities between the onshore and offshore areas are consistent with the seismic interpretations that submerged continental crust extends almost to the front of the Peru margin. Before the Oligocene, the crust now at the front of the continental margin appears to have been part of a broad continental shelf. The Eocene sequence at Site 688 , which was then at shelf depths, is now $4.4 \mathrm{~km}$ deep. In seismic record CDP-1, the corresponding Eocene reflections extend to a point only $15 \mathrm{~km}$ landward of the trench axis, at a present water depth of about $6.2 \mathrm{~km}$. Thus, we assume that subsidence of the continental crust at the front of the margin along the Lima Basin has been a dominant vertical tectonic response during convergence and subduction of the Nazca Plate.

The landward stratigraphic control point (Site 679) provides a section that is readily correlated across the Lima Basin by seismic stratigraphy. Particularly significant is the hiatus between 7 and $11 \mathrm{Ma}$ at 245 meters below the seafloor (mbsf). When reflections from the hiatus are followed downslope, they indicate the profound angular unconformity that becomes the floor of the entire Lima Basin. In CDP-1, the 60-km-wide angular part of the unconformity is buried under $1200 \mathrm{~m}$ of sediment deposited in a sequence of landward-migrating depocenters beneath the midslope terrace. The degree of angular discordance, the estimated $1 \mathrm{~km}$ of sediment eroded at the unconformity, and the broad extent of the erosional surface indicate that the unconformity was subaerially exposed. This unconformity is $3.4 \mathrm{~km}$ deep at the present depocenter. Subsidence from a sea-level position at $6 \mathrm{Ma}$ (median age of the hiatus at Site 679) yields a rate of $490 \mathrm{~m} / \mathrm{m} . \mathrm{y}$. This rate compares with that of $500 \mathrm{~m} / \mathrm{m} . \mathrm{y}$. determined from benthic foraminifer assemblages in sediment dredged from the seaward flank of the Lima Basin (Kulm et al., 1984). Seaward along the lower slope, benthic foraminifers indicate subsidence at about $400 \mathrm{~m} / \mathrm{m}$.y. during the past $8 \mathrm{~m}$.y. (Fig. 3 ). The shallow water depth of today's lower slope is indicated by the recovery of upwelling sediment facies at both Sites 688 and 682 , a facies now forming in water no deeper than $450 \mathrm{~m}$. Thus, results from drilling on either flank of the Lima Basin amplify the indication of subsidence as was previously deduced from dredging results.

The buried ridge that separates the upper- and middle-slope terraces (Fig. 3) formed either an emergent barrier or insular platform composed of shelf sediment and was uplifted between middle and late Miocene time. Seaward of this barrier, coastal upwelling occurred. Erosion of the insular platform supplied the abundant reworked and transported material in the middle and upper Miocene section recovered from Sites 682 and 688, located seaward. Apparently, the Lima Basin area was uplifted during the late Miocene, eroded between 7 and $11 \mathrm{Ma}$, and subsided rapidly after about $5 \mathrm{Ma}$. At this time, the sequence of Pliocene and Quaternary lens-shaped seismic packets accumulated in landward-shifting sequences recognized in seismic images.

The upper Neogene plate-tectonic history indicates subduction of the Nazca Ridge near the southern corridor between 7 $\mathrm{Ma}$ (when the southern flank of the ridge began to be subducted) and 2.5 Ma (when the trailing edge passed) (Cande, 1985; Nur and Ben-Avraham, 1981). The period of accelerated plate convergence occurred between 8 and $5 \mathrm{Ma}$. It seems that the subsidence of the Lima Basin occurred after accelerated convergence and during subduction of the Nazca Ridge. However, during the same period the Trujillo Basin appears to have been uplifted, whereas the Salaverry Basin remained relatively stable with no more than $100 \mathrm{~m}$ of subsidence at the central position occupied by Site 680 . Plate-tectonic history offers no simple explanation of vertical tectonism of these forearc basins.

\section{PALEOENVIRONMENT OF FOREARC BASINS}

\section{Upwelling Oceanography}

Paleoceanographic drill sites were located beneath the strongest wind-driven upwelling areas of the Peru Current regime (Fig. 1). Today, this region is situated along the upper continental slope at water depths between 150 and $500 \mathrm{~m}$. The sites were arranged along a north-south transect (Sites 684, 679, 687, and 686) and an east-west transect (Sites 681, 680, and 679; Fig. 1; Table 1). The sites straddle the critical depth range of the oxygen-minimum zone at the present sea level and at lower sea-level stands in the past (150 to 400 meters below sea level, mbsl) (Fig. 5). Comparing the sediment records along these transects provides criteria for a detailed identification of coastal upwelling signals needed for reconstructing the water-column parameters (temperature, nutrients, oxygen), of upwelling ecology (diatoms, coccoliths, and foraminifers), of the interaction between shelf and slope morphologies, and of currents of the Peru upwelling system (coastal current, poleward undercurrent).

\section{North-South Transect}

Four sites $(684,679,687$, and 686$)$, between $9^{\circ}$ and $13^{\circ} 30^{\prime} \mathrm{S}$ at a water depth of approximately $400 \mathrm{~m}$ (ranging from 306 to $450 \mathrm{~m}$ ), show that the Quaternary sediment record thickens enormously-from $14 \mathrm{~m}$ in the north to $>300 \mathrm{~m}$ in the south. This change is tectonically controlled. Sedimentation at the southernmost point (Site 686) reflects the subsidence of the West Pisco Basin, while the condensed record in the north reflects the 


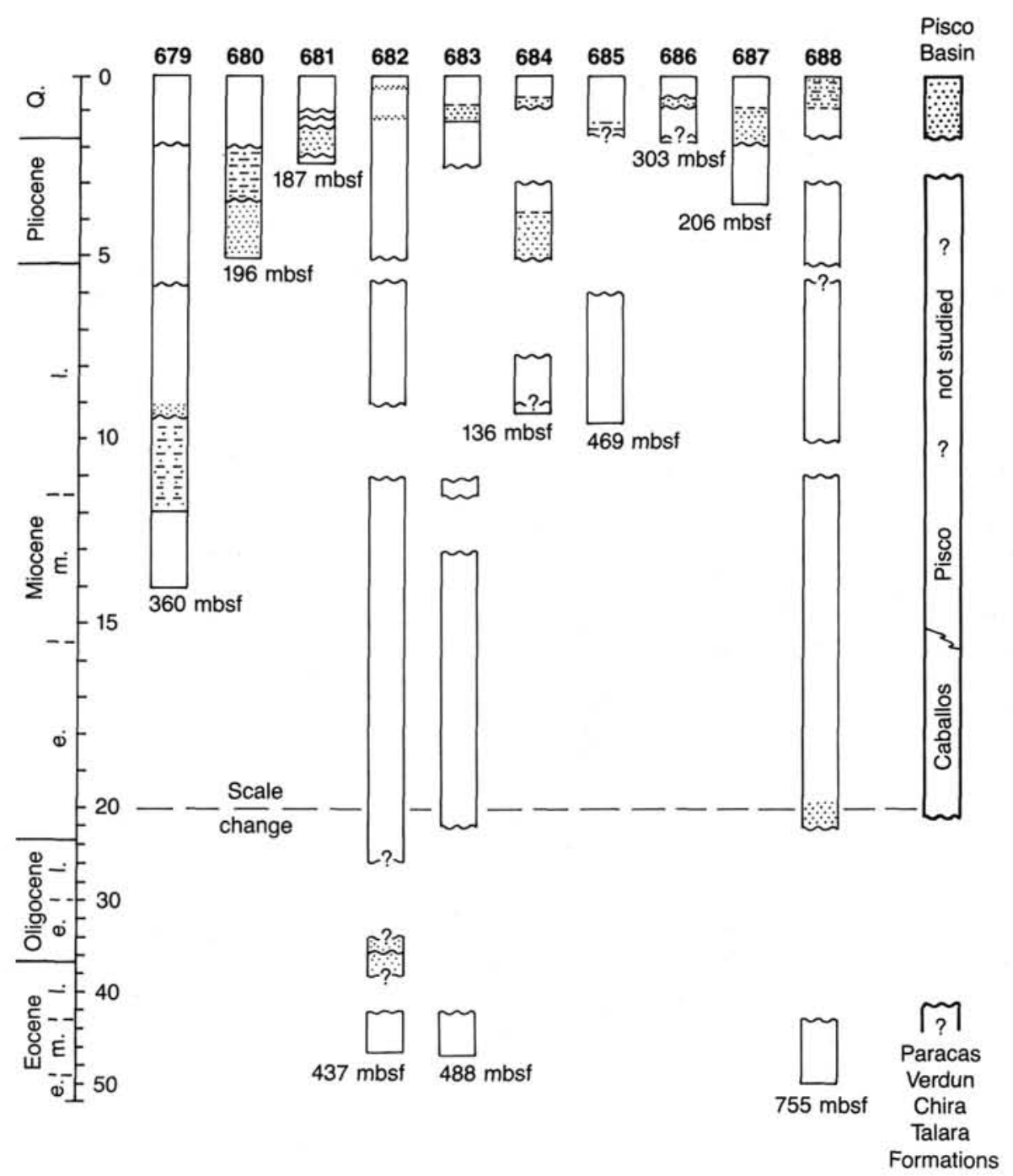

Figure 4. Summary of stratigraphic hiatuses and sand facies indicating erosion recognized in Leg 112 cores. The regional hiatus that typically includes all Oligocene sediment and locally ranges from early Eocene to middle Miocene is also displayed in reprocessed seismic records (see von Huene and Miller, this volume). Sites drilled on the shelf and upper slope commonly display a hiatus of middle Miocene age. These hiatuses were also recognized in onshore exposures, as depicted in the right column.

vertical oscillations of a structural ridge at the outer shelf bounding the Trujillo Basin. Generally, the early Quaternary sediments are more bioturbated, while the late Quaternary sediments are laminated. The Pliocene/Pleistocene boundary at all sites coincides with the development of a shallow-water environment of outer-shelf character (50-150 m water depth) because of lower sea-level stands globally. Such a coherent facies distribution over the length of the transect, spanning more than 600 $\mathrm{km}$, indicates that all the sites, now located at the lower boundary of the oxygen-minimum zone (about $400 \mathrm{~m}$ water depth), have traversed the center of the oxygen-minimum zone at least once. The observed variation in facies composition within these deposits must reflect that vertical transit.

The uppermost Quaternary lithostratigraphic record is characterized by laminated diatomaceous muds at all sites of the transect. This is consistent with deposition of an upwelling facies at today's water depth. Studies concerned with latitudinal shifts of upwelling centers, with the changing location of the oxygen-minimum zone through time, and with bulk and component accumulation rates can rely on complete and representa- tive sections along this north-south transect. Alternating bioturbated and laminated sequences are particularly prominent at Sites 679,686 , and 687.

The Pliocene record recovered at the sites on the north-south transect shows the same latitudinal characteristics, except that this interval was not recovered at Site 686. As with the Holocene and Pleistocene, the Pliocene facies alternate between laminated and bioturbated diatomaceous muds and indicate a long and continuous history of upwelling. An upper Miocene record was recovered only at Sites 684 and 679 . The sparse diatom content at Site 679 indicates that during this time the site was located near the shore, at water depths too shallow to preserve sedimentary signals of coastal upwelling. At Site 684, located farther to the west, the Miocene section was deposited in slightly deeper water and thus contains a better upwelling record.

The detailed sedimentary records of late Miocene, Pliocene, and Pleistocene-Holocene upwelling obtained by drilling along the transects do not go back to the beginning of the coastal upwelling history along the Peru margin because of the tremendous subsidence of the upper slope before middle Miocene time. How- 

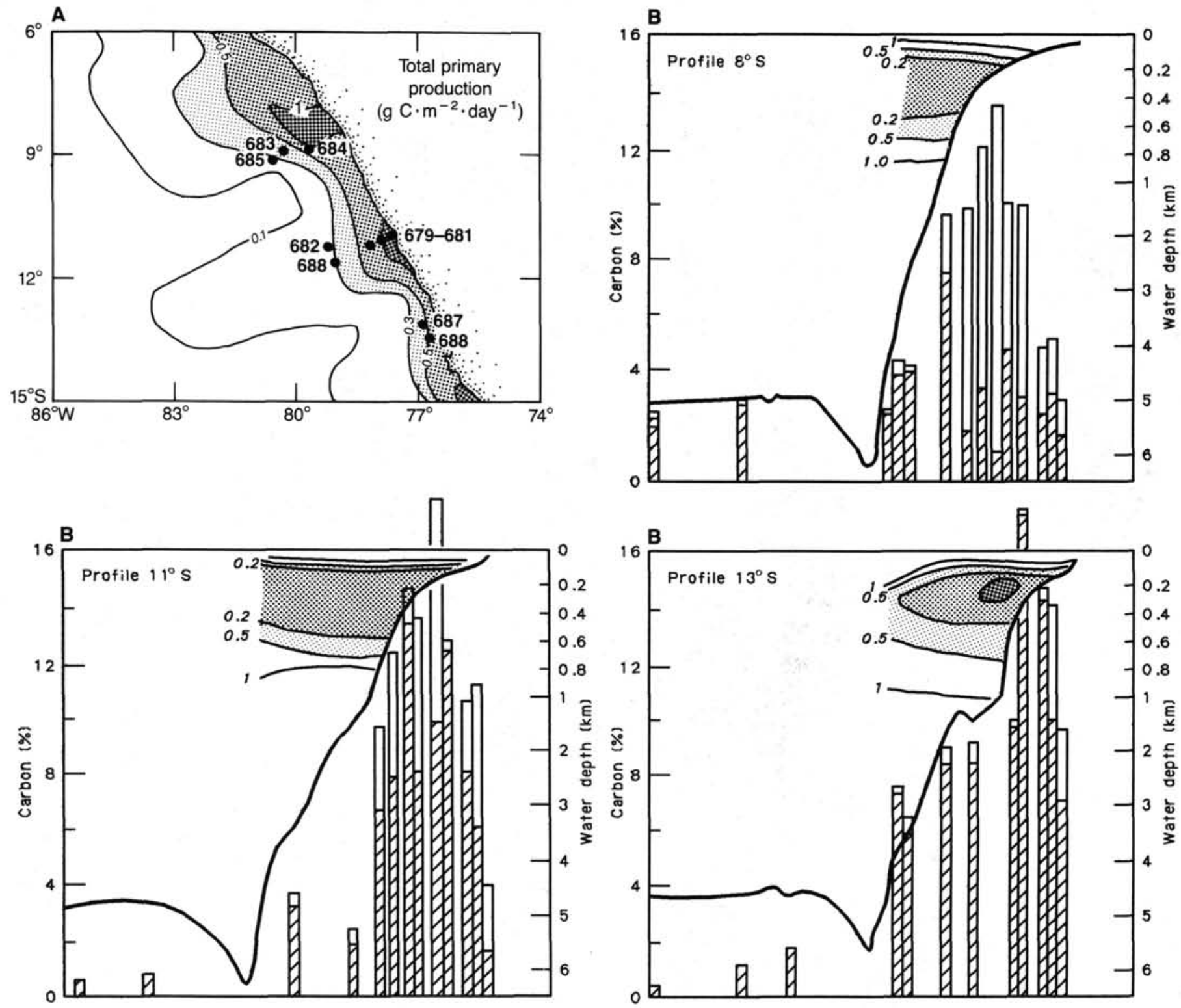

Figure 5. A) Upwelling centers along the Peru Continental Margin, as delineated by the maxima in integrated-mean, long-term primary production $\left(>0.5 \mathrm{~g}\right.$ carbon fixed $\left[\mathrm{m}^{2} / \mathrm{d}\right]$ ) and $\left.\mathrm{B}\right)$ vertical offshore distribution of dissolved oxygen $(\mathrm{mL} / \mathrm{L})$; the sedimentary organic carbon (wt $\% \mathrm{C}_{\text {org }}$; crosshatched) and calcium carbonate (wt \% $\mathrm{C}_{\text {calcite }}$; blank) distributions are shown in relation to water depth and oxygen; modified from Reimers and Suess (1983). Note positions of drill sites.

ever, recovery of slump blocks with upper Miocene laminated sediments at $400 \mathrm{mbsf}$ at Site 688 and $110 \mathrm{mbsf}$ at Site 682 suggests that late Miocene coastal upwelling was confined to the seaward edge of the present Lima Basin about $100 \mathrm{~km}$ west of today's upwelling centers (Fig. 6). Such a record contains a primary signal of upwelling comparable to the Quaternary record evident in the present shelf basins (Fig. 7).

\section{East-West Transect}

Three sites were drilled at approximately $11^{\circ} \mathrm{S}$ representing a water-depth transect across the outer shelf $(679$ at $450 \mathrm{~m}, 680$ at $253 \mathrm{~m}$, and 681 at $151 \mathrm{~m}$ ). A fourth site, Site 688 at $3820 \mathrm{~m}$, extends the transect to midslope depth. The two shallower sites are located in the Salaverry Basin, while Site 679 is on the seaward flank of the structural ridge separating the Lima Basin from the Salaverry Basin and Site 688 beyond the western edge of the
Lima Basin. The structural ridge separating the Lima Basin from the Salaverry Basin was subaerially exposed, forming either an emergent barrier or insular platform, and confined during the Miocene, which also confined the Salaverry depositional basin to a restricted environment east of the ridge. Consequently, no Miocene upwelling record was ever deposited here. The isolation of the Salaverry Basin continued throughout the Pliocene. Only since the beginning of the Quaternary period has strong coastal upwelling started as a result of basin and ridge subsidence and a rise in sea level. However, this record is expanded, continuous, well-preserved, and contains only minor amounts of terrigenous detritus. Thus, it is an ideal record to use for reconstructing a high-resolution Quaternary upwelling history.

Shipboard investigations indicated that variations in the amount and type of organic matter, the diatom flora, magnetic intensity, the physical properties, and water contents in these 


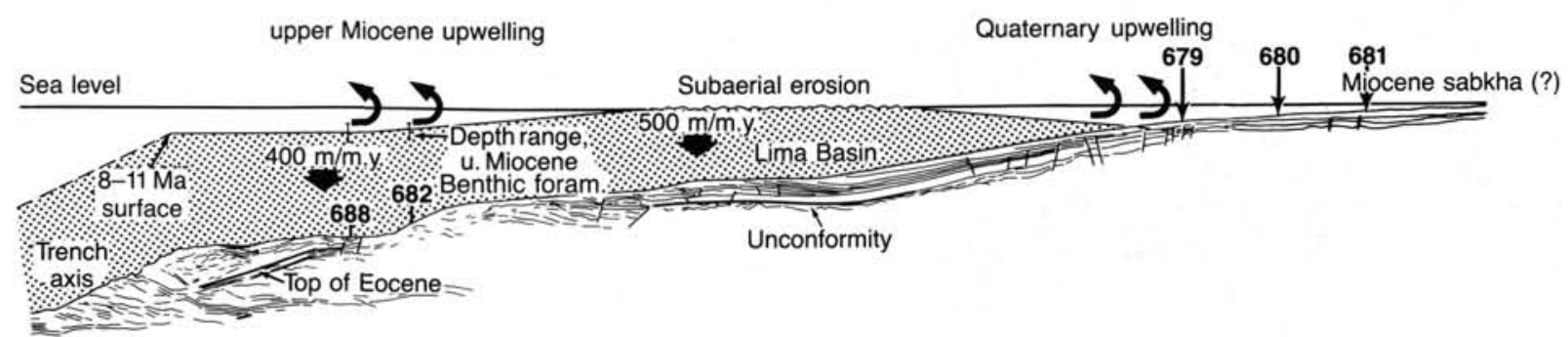

Figure 6. Subsidence of Lima Basin as indicated by benthic foraminifer assemblages, coastal upwelling facies, and the 8-11-m.y. unconformity and associated hiatus. Note landward migration of upwelling centers between upper Miocene time and today's position of coastal upwelling.
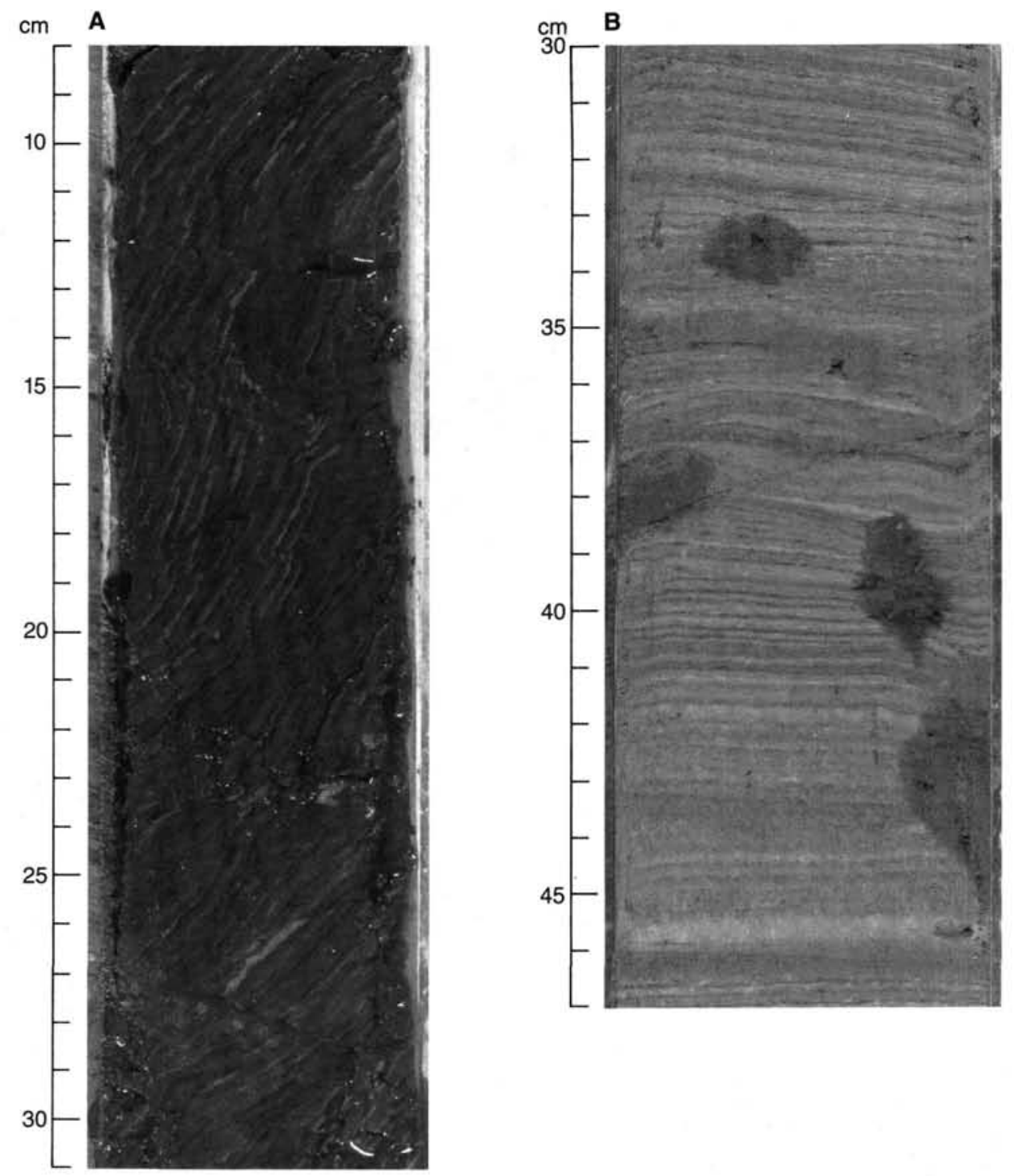

Figure 7. Diatom- and organic-carbon-rich, laminated upwelling facies deposited in the shallow oxygen-minimum zone of the forearc basins; A) compacted, folded, and microfaulted sediments of upper Miocene age from Site 688 (Section 112-688E-6R-7) and B) undeformed and uncompacted sediments of upper Quaternary age from the West Pisco Basin (Section 112-686A-3H-4).

sediments appear to correlate with major glacial/interglacial cycles. The large sea-level fluctuations during the Quaternary have not erased the upwelling record because tectonic subsidence during deposition maintained optimal water depth for its preservation. The record obtained at Site 686 , at the southernmost end of the Lima Basin, is of the same quality and resolution as that at Sites 680 and 681 . Together the three sequences will allow us to study in detail the history of coastal upwelling when the final chronologic, lithologic, and biostratigraphic correlations are established. 


\section{Cyclicity}

The Quaternary sequences in the Salaverry Basin (Sites 680 and 681) and the West Pisco Basin (Sites 686 and 687) contain laminations on a millimeter and submillimeter scale. Shipboard data for magnetic intensity, water content, wet-bulk density, porosity, and organic carbon revealed cyclic fluctuations of these properties over a scale of meters or less. Also, interbedding of laminated and bioturbated diatomaceous mud units at even lower frequencies (tens of meters) suggests alternations between a lowenergy, low-oxygen depositional environment and high-energy environments with substantial terrestrial input and enhanced sediment reworking in more oxygenated water. We suspect that the cyclicity in the upwelling facies off Peru is climatically forced. To recognize and evaluate such high-resolution climatic signals are among the basic objectives on which any of the future studies of ancient coastal upwelling along the Peru margin must rely. For this reason, we attempted to obtain a preliminary idea about the length of time and frequency of these cyclic alternations to assess their usefulness in paleoceanographic reconstructions and, eventually, to speculate about their causes.

At Site 680 , the magnetic intensity pattern of sediments oscillates over the last $0.73 \mathrm{~m}$.y. and is synchronous with the organic carbon content. Particularly noteworthy are the high organic carbon values, which coincide with high magnetic intensities (Fig. 7). In the absence of a high-resolution chronology, we speculate that these alternations might be related to glacial/interglacial cycles comparable in time duration to those commonly obtained from the oxygen-isotope stratigraphy. The high magnetic intensities apparently result from increased production of microbial biomagnetite in the organic-rich, anoxic environment characteristic of the coastal upwelling regime. Such a relationship was observed in the upwelling sediments of the Santa Barbara Basin (Kirschvink and Chang, 1986) and in the Miocene deposits-also affected by upwelling-of the Angola Basin (Petersen et al., 1986; von Dobeneck, 1987). Input of magnetic carriers from terrigenous sources should result in the opposite relationship between organic carbon content and magnetic intensity.

At Site 686 , the alternations between laminated and bioturbated lithologies represent long-term oscillations of oxygen levels in the water column and perhaps also of sea levels. Based on shipboard magnetic reversal data and a $\mathrm{K} / \mathrm{Ar}$ age obtained from an ash layer, we calculated sedimentation rates of $60 \mathrm{~m} / \mathrm{m}$.y. for lithologic Unit I and $180 \mathrm{~m} / \mathrm{m}$.y. for the other five units at Site 686. The estimated durations of these units are shown in Table 2. Assuming that they record high and low stands of sea level, each adjacent pair might then represent one of three complete cycles of sea-level change. These are designated A, B, and C, and their tentative durations and ages of cycle boundaries are listed in Table 2.

For the time interval represented by the sediments at Site 680 (i.e., 0-2 m.y. ago) Haq et al. (1987) recognized three third-order cycles of sea-level change. The durations, boundary ages, and downlap-surface ages (the downlap-surface age corresponds to the age of maximum flooding during a rise in sea level) for each of these globally recognized cycles are listed for comparison in Table 2. Good agreement was observed between global cycles and those tentatively recognized at Site 686 . Lithologic Unit I contains numerous phosphatic layers, which may be a condensed sequence in which a complex history of sea-level change became greatly compressed. We should emphasize that several Quaternary specialists consider the time-resolution of the major Quaternary cycles proposed by Haq et al. (1987) as not detailed enough, preferring instead numerous, shorter-term glacial/interglacial cycles (Shackleton, pers. commun., 1987; Imbrie et al., 1984; Pisias, 1984). These shorter cycles are doubtless present within the larger cycles, as suggested by the lithologies of Site 680 .

\section{Upwelling Signals}

Diatom frustules and organic matter are by far the most abundant and common biogenic components of the upwelling facies. Silicoflagellates, sponge spicules, and radiolarians usually occur, and calcareous nannoplankton are seen occasionally. Planktonic and benthic foraminifers are abundant in certain cores and may allow us to perform a detailed reconstruction of upwelling character and intensity; usually however, calcareous microfossils are rare.

The diatom record throughout the Quaternary indicates influence of warm- and cold-water masses at various times. In addition, diatoms commonly occur in the form of monospecific assemblages indicative of blooms. Sites 686,687 , and 681 , located beneath present-day upwelling plumes, contain the most detailed and best-resolved diatom records. At these sites the floras indicate different intensities of coastal upwelling with the associated nutrient availability. These assemblages can be classified as indicative of (1) strong upwelling, (2) intermittent upwelling, (3) no upwelling but high fertility, and (4) normal continental margin fertility. Various combinations and modifications of such qualitative upwelling character are manifest throughout the cores at these sites. However, the shipboard sample resolution is not detailed enough to relate these upwelling phases to any of the

Table 2. Cycles at Site 686.

\begin{tabular}{|c|c|c|c|c|c|c|c|c|c|}
\hline \multirow[b]{2}{*}{$\begin{array}{l}\text { Lithologic } \\
\text { unit }^{\mathrm{a}}\end{array}$} & \multirow[b]{2}{*}{$\begin{array}{l}\text { Thickness } \\
\text { (m) }\end{array}$} & \multirow[b]{2}{*}{$\begin{array}{l}\text { Duration } \\
\text { (m.y.) }\end{array}$} & \multirow[b]{2}{*}{ Sea level } & \multicolumn{3}{|c|}{ Quaternary cycles at Site 686} & \multicolumn{3}{|c|}{$\begin{array}{l}\text { Neogene cycles of sea-level changes } \\
\text { (Haq et al., 1987) }\end{array}$} \\
\hline & & & & Cycle & $\begin{array}{l}\text { Duration of } \\
\text { cycle (m.y.) }\end{array}$ & $\begin{array}{c}\text { Age of cycle } \\
\text { boundaries (m.y.) }\end{array}$ & $\begin{array}{l}\text { Duration } \\
\text { (m.y.) }\end{array}$ & $\begin{array}{c}\text { Age of cycle } \\
\text { boundaries (m.y.) }\end{array}$ & $\begin{array}{l}\text { Downlap surface } \\
\text { age (m.y.) }\end{array}$ \\
\hline I & 28 & 0.46 & High stand & & & 0 & & 0 & 0.006 \\
\hline II & 73 & 0.40 & Low stand & A (Units I and II) & 0.86 & & 0.8 & & \\
\hline III & 53 & 0.29 & High stand & & & 0.86 & & 0.8 & 1.3 \\
\hline IV & 76 & 0.42 & Low stand & B (Units III and IV) & 0.71 & & 0.8 & $=$ & \\
\hline V & 35 & 0.19 & High stand & $\begin{array}{l}\mathrm{C} \text { (Units } \mathrm{V} \text { and } \mathrm{VI} ; \\
\text { base not exposed) }\end{array}$ & $0.46+$ & 1.57 & 0.8 & 1.6 & 2.0 \\
\hline VI & $48+$ & 0.27 & Low stand & & & $2.03+$ & & 2.4 & \\
\hline
\end{tabular}

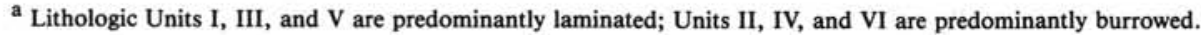


observed cyclicities discussed previously. At Site 684 , the late Miocene upwelling environment was characterized by numerous blooms of diatoms and coccoliths closely associated in laminations. These assemblages indicate high nutrient supply during brief warm and cold phases that alternate drastically. Perhaps the warm phases represent periods during which upwelling was seeded by equatorial waters, a phenomenon observed today only in abnormal oceanographic situations, such as El Niño conditions.

Of the planktonic foraminifers, five cool-water species indicating upwelling were identified, particularly in cores from the east-west transect. These are Globigerina bulloides, G. quinqueloba, Globigerinita glutinata, Neogloboquadrina dutertrei, and $N$. pachyderma. These same species were observed previously in plankton samples from surface waters of the Peru upwelling regime, where they display a distinct zonation in upwelling centers (Thiede, 1983). Their stable carbon- and oxygen-isotope composition should yield valuable information about water-column parameters. Also, as previously observed, certain genera develop abnormally small calcareous tests. While ecological reasons are currently unclear, a cause such as low oxygen contents of upwelling waters is suspected (Wefer et al., 1983).

Benthic foraminifer assemblages, when present in sufficient numbers, record the successive habitats from outer-shelf to upper-bathyal depths during subsidence/eustatic sea-level fluctuations and, more importantly, may yield information about the bottom-water oxygen contents from their stable-isotope composition. With independent information from lithological data about sea-level fluctuations, these benthic assemblages should help differentiate tectonic changes from eustatic changes in water depths along the Peru upwelling regime.

Organic matter, measured in quantity and quality by pyrolysis and by various solvent extractions, seems the richest carrier of upwelling signals, while at the same time it is the most difficult one to resolve. Total organic carbon (TOC) contents vary widely, from $12 \mathrm{wt} \%$ to $2 \mathrm{wt} \%$. Cyclicity was indicated from buried TOC contents at several sites, as illustrated for Hole $680 \mathrm{~A}$ in Figure 8. Both dilution from terrigenous clastics and changing input from biological production account for the observed changes. Detailed chronostratigraphy is needed to convert these data to accumulation rates, which then should readily reflect absolute changes in primary production as a measure for upwelling variability. While the hydrogen and oxygen indices (HI and OI, respectively) derived from Rock-Eval pyrolysis indicate marine plankton is the overwhelming source of the sedimentary organic matter, some samples exhibit anomalously high OI values. Interpreted conventionally, these values might reflect either terrestrial origin of organic matter or oxydative decomposition as they were found near unconformities. However, interpretation of this signature to indicate terrigenous sources should be used with caution when applied to fresh organic matter rich in natural oxygenated organic compounds.

\section{Diagenesis}

Decomposition of organic matter by anaerobic microbial processes (mainly by sulfate and carbonate reduction) is the dominant reaction mechanism observed in sediments at all sites during Leg 112. The sulfate-reduction zones extend downhole to various levels and are usually followed by zones of methanogenesis, except at sites where a brine replenishes the diminished interstitial sulfate reservoir from below. This exceptional phenomenon was observed at the shelf sites and will be discussed separately. The dominance of anaerobic sulfate- and carbonatereduction reactions results from the large amount of organic matter and the rapid rates of burial at all sites. The burial flux of organic matter is so large in comparison to the rate of decomposition that it represents an inexhaustible supply for mi- crobial activity; hence these reactions are not substrate-limited, as is the case in other deep-sea sediments. Instead, the observed depth zonation of sulfate reduction and methanogenesis is a reflection of the dynamics between the bulk-sedimentation rate and the diffusional supply of sulfate.

\section{Sulfate Reduction and Nutrient Regeneration}

The inferred bulk-sedimentation rates from the interstitialsulfate-reduction profiles of all sites are compared with the rates estimated from biostratigraphy (Table 3 ). Good relative agreement exists between these two methods of estimation, except that the rates based on sulfate reduction are larger by a factor of two. Possibly the empirical relationship first used by Berner (1978) in nearshore environments and later expanded by Reimers and Suess (1983) to include hemipelagic deposition is biased toward nearshore and shallow-water environments, or the sulfatereduction rate may not be a simple function of sedimentation rate. Another likely explanation for the discrepancy may be that rates based on biostratigraphy are inherently minimum rates as they include, and in some cases amplify, small hiatuses.

The high bulk-sedimentation rates limit the upward exchange of metabolites with the overlying seawater. This causes high concentrations of ammonia, phosphate, hydrogen sulfide, methane, and alkalinity to build up within the pore water and is responsible for the observed record concentrations of these metabolites, particularly at Sites 685 and 688 . The alkalinity, ammonia, and phosphate contents at these sites are the highest ever observed during DSDP and ODP drilling. Samples from this extreme chemical environment will allow us to study a number of diagenetic processes with a detail not possible elsewhere. These studies include ion-exchange reactions involving ammonia and the formation of carbonate, sulfide, and phosphate, minerals, and gas hydrates.

\section{Diagenetic Calcite and Dolomite}

The intense sulfate reduction and methanogenesis encountered at all sites and the abundance of calcite and dolomite crusts, concretions, and dissemimated euhedral crystals confirmed that the shallow and deep forearc basins along the Peru continental margin are excellent sites for examining the conditions that lead to the formation of "organic" dolomites. Organic dolomite refers to the source of carbonate-ion formation, which is either microbial or thermal degradation of sedimentary organic matter. Baker and Kastner (1981) showed the necessity for sulfate depletion before dolomitization may begin. Since that time, it is evident that dolomite formation in organic-rich sediments, such as those of the upwelling facies of the Peru margin, is a diagenetic process that inevitably follows sulfate reduction (Kulm et al., 1984; Baker and Burns, 1985). During shipboard studies, no stable-isotope data were obtained to con-

Table 3. Rate of sedimentation estimated from sulfate reduction compared with biostratigraphically derived sedimentation rates.

\begin{tabular}{cccc}
\hline & $\begin{array}{c}\text { Sulfate } \\
\text { reduction } \\
(\mathrm{mmol} / \mathrm{m})\end{array}$ & $\begin{array}{c}\text { Rate of sedimentation } \\
\text { Site reduction } \\
(\mathrm{m} / \mathrm{m} . \mathrm{y})\end{array}$ & $\begin{array}{c}\text { Biostratigraphy } \\
(\mathrm{m} / \mathrm{m} . \mathrm{y} .)\end{array}$ \\
\hline $112-679$ & 0.15 & 20 & 12 \\
$112-680$ & 0.90 & 100 & 55 \\
$112-681$ & 0.93 & 140 & 80 \\
$112-682$ & 0.40 & 40 & 26 \\
$112-683$ & 1.76 & 180 & 110 \\
$112-684$ & 1.47 & 150 & $35(?)$ \\
$112-685$ & 2.23 & 250 & 130 \\
$112-686$ & 2.26 & 255 & 160 \\
$112-687$ & 1.07 & 105 & 65 \\
$112-688$ & 4.12 & 300 & $150-350$ \\
\hline
\end{tabular}


firm the biogenic source of the carbonate ion; however, we did obtain important interstitial-water data from closely spaced sampling that document a reaction sequence for the complicated process of organic-dolomite formation.

As sulfate reduction proceeds, the most important systematic downhole variations in dissolved calcium, magnesium, and alkalinity reflect carbonate mineral reactions. A change in the ratio of these components does not control the reaction, but rather the change in $\mathrm{Ca}^{2+}$ and $\mathrm{Mg}^{2+}$ is a consequence of diagenetic reactions involving carbonate minerals. At first, calcium profiles invariably show a distinct minimum that reflects calcite precipitation. This causes the $\mathrm{Mg} / \mathrm{Ca}$ ratio to increase. At Sites 683 and $685 \mathrm{Mg} / \mathrm{Ca}$ ratios as high as 13 and 17 were measured; these are the most extreme values ever reported from nonevaporative environments. Dolomitization by calcite replacement then reverses this trend until the $\mathrm{Mg} / \mathrm{Ca}$ ratio decreases to less than a value of 2 . Under these conditions, calcite and dolomite continue to co-precipitate. Concurrent changes in alkalinity indicate whether direct stoichiometric precipitation occurs, or whether replacement reactions dominate.

The distribution of diagenetic calcite and dolomite observed in sequences of the shelf and midslope sites supports this reaction sequence. Both mineral phases begin to form within the sulfate-reduction zone, in some instances as shallow as $1 \mathrm{mbsf}$ (Site 687 at $0.7 \mathrm{mbsf}$ ). At the midslope sites, carbonate precipitates only at comparatively great burial depths (Site 682 at 108 mbsf; Site 683 at 422 mbsf). Calcite precipitation generally precedes dolomite precipitation; disseminated rhombs in muds precede lithified beds or nodules.

More authigenic carbonates occur in the shelf sediments than in slope sediments. The slower rates of bulk sedimentation on the shelf may allow larger fluxes of dissolved calcium and magnesium to reach those layers at shallow subsurface depths where carbonate mineral diagenesis takes place. Also, the carbonate, calcium, and magnesium influx may be enhanced by diffusion from the brine, which was discovered in the subsurface over the entire shelf area. The many stages of dolomite and diagenetic carbonate formation can be seen particularly well in the cement stratigraphy of brecciated rocks and cemented sands and in the laminated muds from this shelf. One can deduce the temporal succession of precipitation environments and the compositional evolution of the pore fluids from the cement stratigraphy. In Figure 8, laminated carbonate cements (tainted with disseminated, black opaques) exhibit such a multigeneration sequence that was recovered from Site 684. The matrix is micritic carbonate having cement-filled foraminifer molds. Two cement generations are separated by discontinuous surfaces, which may indicate periods of corrosion. Locally, these generations also are separated by a lens of internal cement. A fourth generation of fracture-filled cement cuts all previous growth zonations.

\section{Phosphates}

Authigenic phosphates occur in two forms: as friable lenses and laminae, and as dense nodular gravels in hardgrounds (Fig. 9). Both types are restricted to shelf and upper-slope sites. Friable phosphates occur mainly in laminated diatomaceous muds formed through regeneration of organically derived phosphorus. The nodular phosphates are complex entities formed through repeated cycles of burial, phosphatization, and exhumation. These phosphates are characteristic for reworked units and condensed stratigraphic sections and commonly mark unconformable surfaces. The most favorable sites for phosphatization along the Peru margin are those shelf and slope regions that were, at least periodically, within the oxygen-minimum zone and that had low sedimentation rates. The midslope sites, where no phosphates were found, are situated below the oxygen-minimum zone and have enormously high sedimentation rates. The low concentra- tions of interstitial dissolved phosphate at the shelf sites and the record high contents measured at the midslope sites support the observed distribution pattern of the solid phosphorite phases.

\section{Gas Hydrates}

The occurrence of methane at all sites drilled during Leg 112 is directly related to the exhaustion of dissolved interstitial sulfate during microbial reduction. This implies that the source of methane is reduction of carbonate ions, an assumption that agrees with the classic model by Claypool and Kaplan (1974). Where sulfate ions are absent, methane occurs in large amounts (on the order of $10^{5}$ to $10^{6} \mu \mathrm{L}$ methane/L wet sediment). These concentrations are minimal because these amounts are the upper limit of methane that can be retained by the sediment as it is brought on deck and decompresses to atmospheric pressure. At such high methane concentrations, which exceed saturation in water, methane-gas hydrates are stable (Kvenvolden and McMenamin, 1980).

Natural-gas hydrates consist of a rigid framework (clathrate structure) of water molecules in which methane is trapped and effectively condensed. These solid substances form under specific pressure and temperature conditions that are encountered in hemipelagic sediments at depths of up to $1100 \mathrm{mbsf}$ and in water depths greater than about 500 mbsf. The stability field of methane hydrates depends on bottom-water temperatures, pressure, and methane concentration. Sediments at all four deepwater sites (Sites 682, 683, 685, and 688; Table 1) drilled during Leg 112 are within this stability field of methane hydrates. Solid pieces of gas hydrates were recovered (Fig. 10) at two of the sites and may have been present at all four.

Shipboard analyses of properties of the observed gas hydrates indicate the predominance of methane over ethane in the hydrate structure. Based on the chloride and salinity values, a variable admixture of interstitial water, or perhaps seawater from drilling that contaminates these samples, was invariably detected.

\section{Interstitial Chloride Patterns and Sources of Low-Chloride Fluids}

During core recovery, gas hydrates dissociate into methane and water and usually are not recovered in solid form. As a result of dissociation, dilution of the interstitial chlorinities in relation to the amount of hydrate is observed, which unambiguously signals the presence of gas hydrates in the subsurface. Such a dilution artifact was observed in the form of sharp, low chloride spikes at all deep sites (Fig. 11; 682, 683, 685, and 688), with values as low as $520 \mathrm{mmol} / \mathrm{L}$ (which is $93 \%$ of normal seawater chloride). In addition, we would expect the formation of gas hydrates to cause true chlorinity and salinity maxima owing to the exclusion of seawater ions from the clathrate structure. Indeed weak maxima were observed immediately above the zone of gas hydrate recovered at Sites 685 and 688 (100 and 140 mbsf, respectively), as well as at Sites 682 and 683, where hydrates were present but not recovered. Under conditions of slow sedimentation rates, the maxima are in communication with the sediment/water interface, so that diffusion tends to straighten out any gradients and thus prevent a build-up of dissolved ions above the concentration of normal seawater. At high sedimentation rates, however, the seawater ions excluded during gas-hydrate formation are trapped below the sediment/water interface. Leg 112 results are the first to document the effects of salt exclusion during gas-hydrate formation.

The actual distribution of gas hydrates within the sediment column is primarily controlled by the rate of methane production. Since production rates often decrease exponentially with depth, we were not surprised that gas hydrates were found at relatively shallow depths, where methane had reached saturation concentrations. Below these levels, gas hydrates were less abun- 


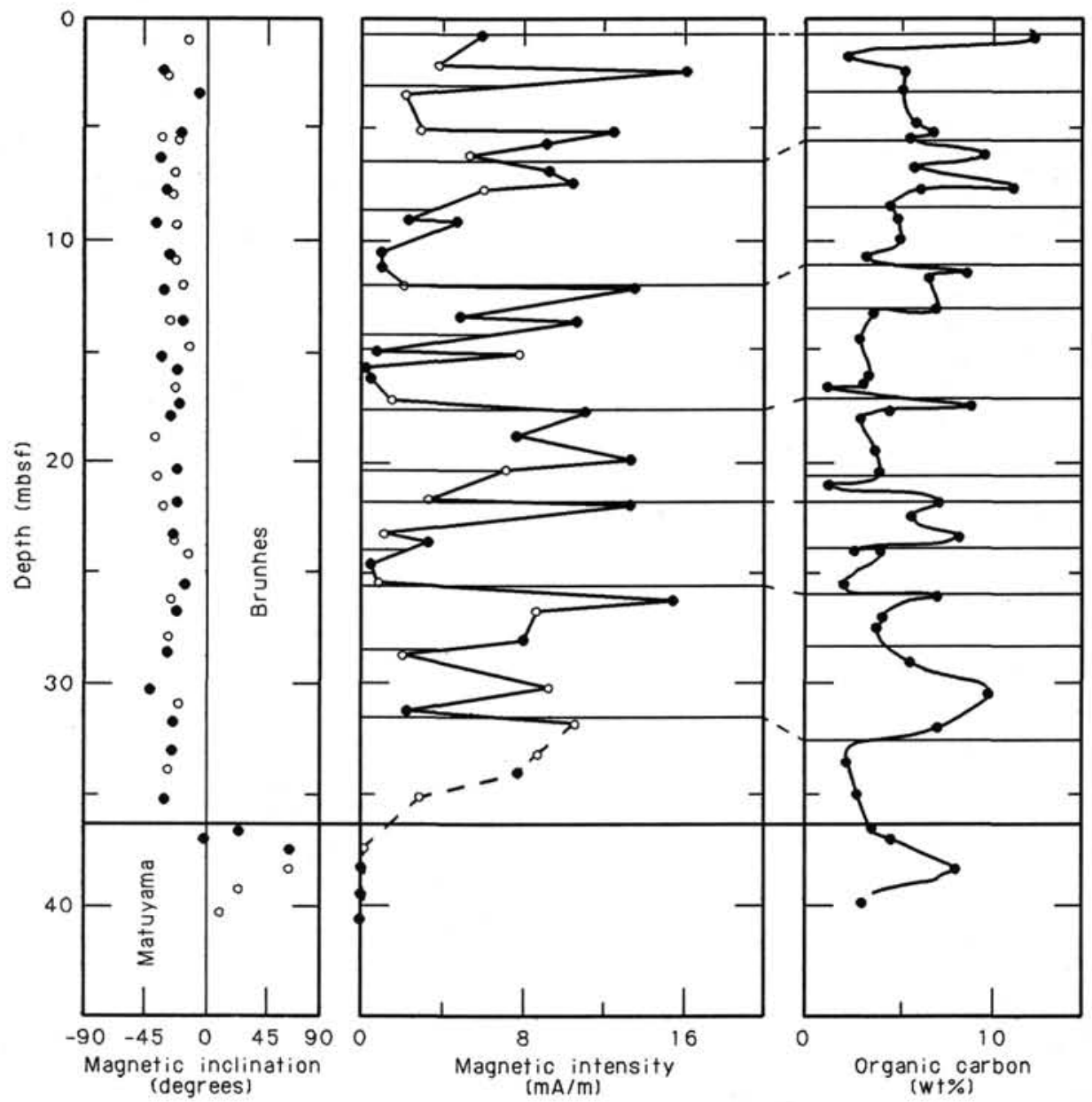

Figure 8. Cyclical deposition of organic carbon during the last $0.73 \mathrm{~m} . \mathrm{y}$. at Site 680 in the Salaverry Basin; the frequency of organic carbon maxima and minima is similar to that of glacial/interglacial cycles; organic carbon maxima are accompanied by high magnetic intensities; we speculate that this coincidence reflects increased production of bacterial biomagnetite during periods of upwelling and accompanied high primary production and intensification of the oxygen-minimum zone. Filled circles represent Hole 680B; open circles indicate Hole 680A. Magnetic intensity at $0 \mathrm{mT}$ demagnetization.

dant and eventually disappeared entirely before the base of the gas-hydrate stability field was reached. This might be part of the reason why the bottom-simulating reflector (BSR), usually assumed to be the transition from solid gas hydrates above to gaseous methane below, was discontinuous. We determined the exact depth for distribution of gas hydrates downhole at Site 685 using density, resistivity, and velocity logs.

The overall chloride pattern in sediments covering the entire midslope shows additional anomalies. A significant decrease in interstitial chloride occurs, with values as low as $475 \mathrm{mmol} / \mathrm{L}$ ( $88 \%$ of normal seawater chloride) at depths $>400$ mbsf. Generally, such large-scale freshening of pore fluids is thought to come from naturally dissociating clathrates at the base of the gas-hydrate stability zone (Hesse and Harrison, 1981). More recently, low-chloride patterns of interstitial fluids in relation to the structural features of the Barbados Ridge complex-where no clathrates occur-were interpreted as evidence of fluid movement along fault planes (Moore, Mascle, et al., 1987). Ultra-filtration during flow of pore waters across clay membranes is the mechanism suggested for separating the ions from the interstitial seawater (Hanshaw and Coplen, 1973; Marine and Fritz, 1981).

Along the Peru margin, the negative chloride anomaly (especially the well-developed minima at Sites 683 and 688) probably is also caused by flow of such chloride-depleted fluids. However, chloride-depletion is not as clearly related to faults as in the Barbados décollement zone, but rather appears related to unconformities, coarse-grained facies units, and conjugate and intersecting fracture zones (Fig. 11). Although clathrate dissociation and clay-membrane filtration are sufficiently convincing processes to explain the chloride pattern of the midslope basins on the Peru margin, the release of chemically bound water at depth from clays and opal could cause equally large anomaly patterns (von Huene and Lee, 1982).

\section{Subsurface Brine}

Different subsurface hydrologic regime and implied fluid flow from those of the midslope basins were discovered on the shelf. Here, strongly increasing salinity gradients in the pore fluids at all sites indicated that a highly concentrated brine exists at depth (Fig. 12). The maximum chloride content measured was $1043 \mathrm{mmol} / \mathrm{L}$, which is equal to $188 \%$ of the value of normal seawater. The chloride gradients appear to be diffusion profiles between this highly concentrated solution and the less saline seawater. We did not reach the depth of the strata containing the brine in any of the holes, although at Site 684 we were closest to it, as indicated by the steepness of the gradients. The conservative tracer chloride can be used best to delineate the distribution 

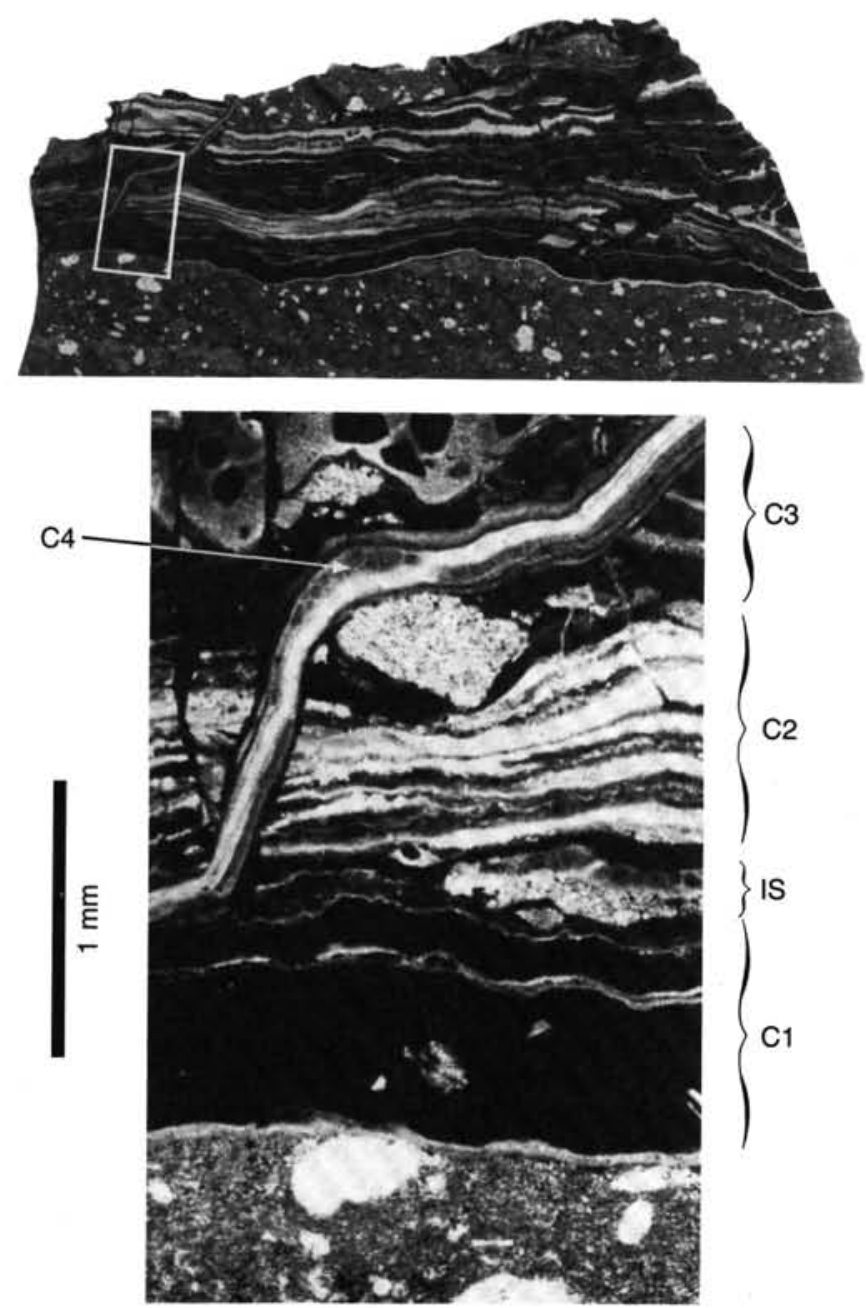

Figure 9. Multiple generations of diagenetic carbonate cements at Site 684 (Sample 112-684A-13X, CC [0-3 cm]); laminated carbonate cement $\mathrm{C}_{1}$ contains disseminated black opaques; the matrix is micritic carbonate with cement-filled foraminifer molds; cement generations are separated by discontinuity surfaces $\left(C_{2}\right.$ and $\left.C_{3}\right)$; a final generation of fracture-filled cement cuts all previous growth zonations $\left(\mathrm{C}_{4}\right)$.

of the brine over the Peru upper shelf and slope. The other dissolved constituents participate in various diagenetic reactions, and thus their distribution primarily indicates the origin and evolution of the brine during passage through the subsurface. Calcium, magnesium, and sulfate participate in carbonate mineral diagenesis and sulfate-reduction processes. Phosphate and ammonia are regenerated from organic matter during sulfate reduction and accumulate in the brine as it passes through organic-rich sediments.

The dissolved sulfate and methane distributions at Site 681 demonstrate the control that the brine exerts on early diagenesis (Fig. 13). The high organic-carbon contents and the high sedimentation rates at this site drive microbial sulfate reduction to completion at a depth of $27 \mathrm{mbsf}$, and a zone of methanogenesis develops below. However, at greater depth, beginning around $100 \mathrm{mbsf}$ and within the zone of high salinity, sulfate is replenished from below and methanogenesis again ceases. In that way, three distinct zones of early diagenesis coexist, in each of which dolomite and calcite form. We suspect that a distinct brine signature occurs in the stable-isotope composition of these various diagenetic carbonates.

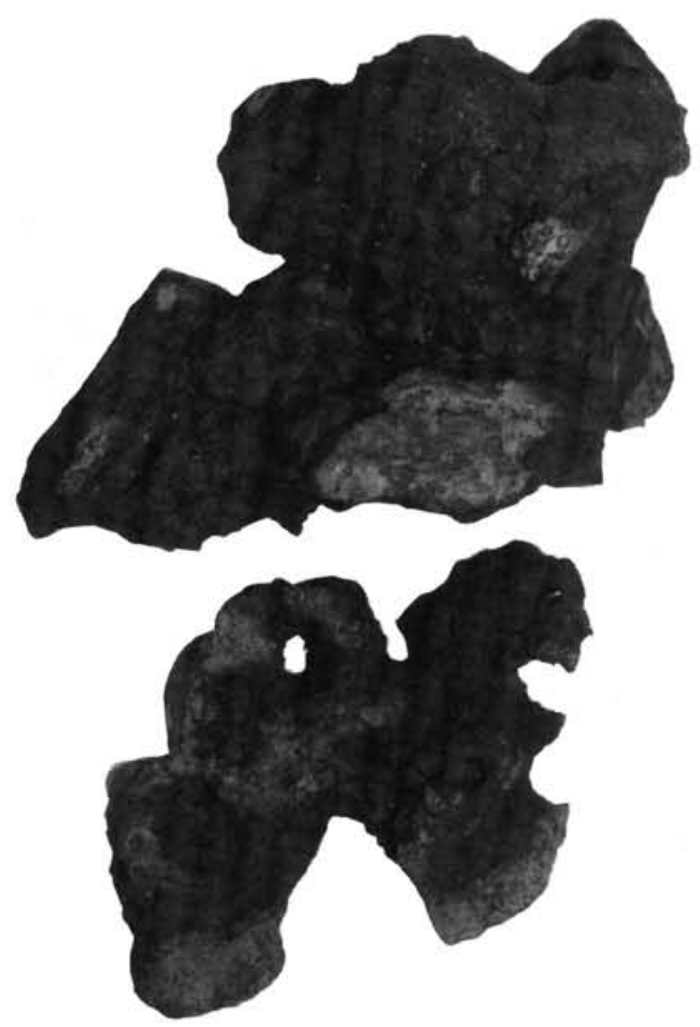

Figure 10. Phosphatic hardground of Quaternary age (Section 112-686A2H-2).

A clear trend of decreasing sulfate and increasing ammonia and phosphate concentrations of the brine is seen at Sites 684 , 686 , and 687 , compared with Sites 680 and 681 . The ammonia and phosphate concentrations at these sites show a nonstoichiometric relationship to sulfate reduction and alkalinity, which strongly suggests cumulative injection of these metabolites during subsurface passage of the brine.

At Site 679 , the salinity distribution complicates the pattern of the subsurface distribution of the brine considerably (Fig. 12). Initially, a small chloride increase was observed at 30 to $50 \mathrm{mbsf}$, which then gave way to a chloride decrease significantly below seawater chlorinities. At the bottom of Hole 679E only $62 \%$ of seawater chlorinity was measured, indicating that a hydrological system with freshwater influence exists at depth only $16 \mathrm{~km}$ west of the brine. Two scenarios are possible for explaining these subsurface hydrological regimes: (1) fossil freshwater and sabkha-derived brine were buried in the past or (2) freshwater and brine flow today from the continent and from the Sechura region of northern Peru separately in the subsurface of shelf and upper-slope sedimentary basins.

Figure 14 illustrates one fossil-fluid scenario: to the east of the structural barrier, upper or middle Miocene sequences may be the source of fossil sabkha-derived brines; to the west of the structural barrier, a body of freshwater exists in the same Miocene sections. Subaerial exposure of the structural barrier during late Miocene time caused the restriction of Salaverry Basin, in which the brine may have formed. The subaerial region may have been the recharge area for freshwater that penetrated into the seaward sequence of the Miocene sediments to the west.

The area of the subsurface brine discovered on the Peru shelf and upper slope is enormous and stretches for more than $500 \mathrm{~km}$ over the area drilled during Leg 112. Its source remains 


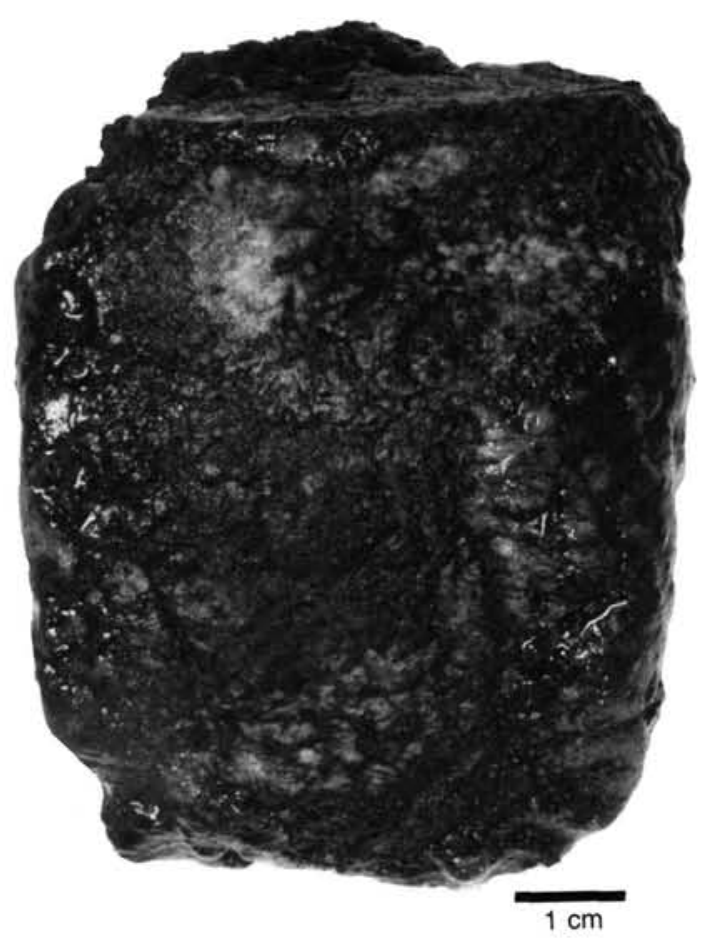

Figure 11. Methane gas hydrate, Section 112-688A-15X-7 at $141 \mathrm{mbsf}$.

speculative. The brine's composition and its subsurface distribution exert a strong influence on early diagenetic processes along the margin and, in particular, drive the widespread formation of diagenetic carbonates by stimulating sulfate reduc- tion and providing calcium, magnesium, and carbonate in excess of normal fluxes.

\section{CONCLUSIONS}

Shipboard studies of samples from the holes drilled during Leg 112 confirmed the inference-deduced before drilling from studying geophysical data, dredged rock, and reports of industry wells - that the crust of continental affinity extends to the lower slope area. The continental affinity of the crust was implied from the distribution of slope sediment, which must postdate tectonic accretion at the front of the margin. These slope sediments extend seaward from the edge of the shelf to the midslope terrace and were inferred to be of Tertiary age (Kulm et al., 1981; von Huene et al., 1985). Leg 112 drilling indicated that the slope deposits are a Neogene section whose base is an Oligocene unconformity observed as a profound hiatus in all the holes drilled to that level. The unconformity is now known from outcrops onshore to within $15 \mathrm{~km}$ of the trench axis and from the Nazca Ridge across the northern Peruvian margin, based on its distinctive signature in seismic records. The regional unconformity was cut during the initial uplift of the modern Andes and during a landward shift in arc volcanism associated with the development of the modern arc-trench system. The underlying Eocene section consists of a shelf and upperslope sediment facies extending about $100 \mathrm{~km}$ seaward of the modern shelf. Remnants of the Eocene shelf and upper slope were sampled at about $450 \mathrm{mbsf}$ and can be recognized at depths of more than $6 \mathrm{~km}$ in seismic records. Regional subsidence dominated the Neogene vertical tectonic history. An example of subsidence during the past 8-11 m.y. (Fig. 3) is well constrained with drill cores of the past shallow-water environment. Those cores include coarse clastic sediment, nonabraded and articulated megafossils, shallow-water microfossil assemblages, and primary upwelling sediment facies.

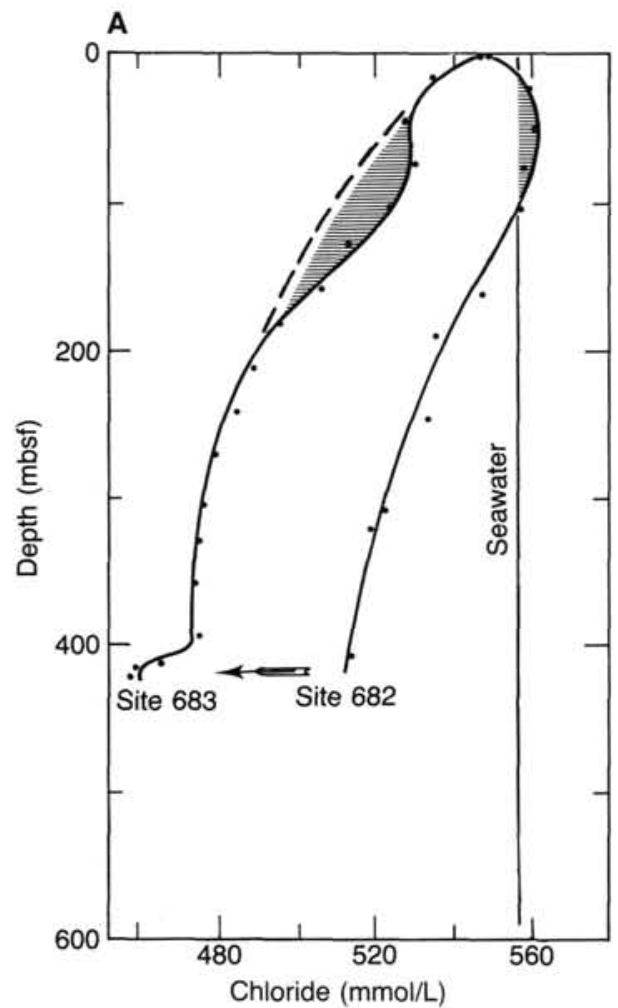

\section{B}

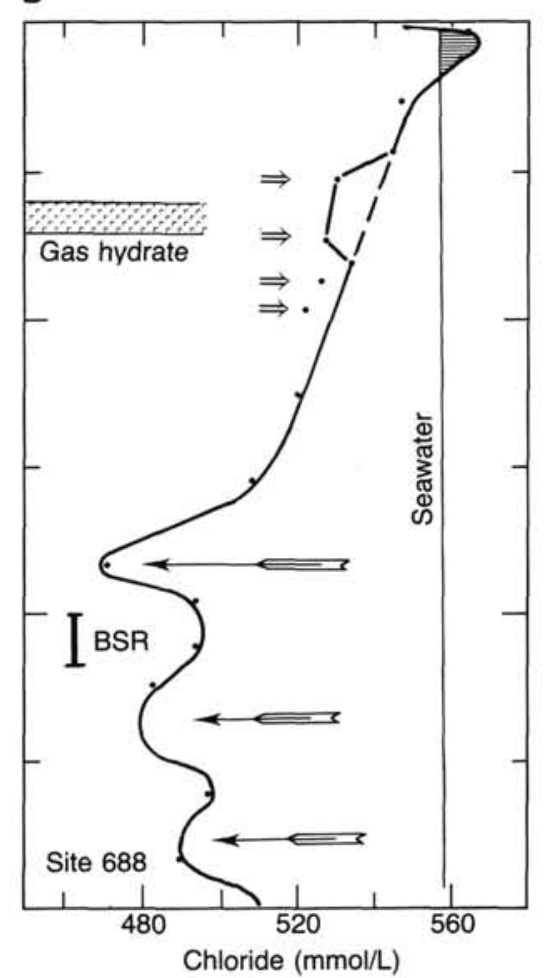

c

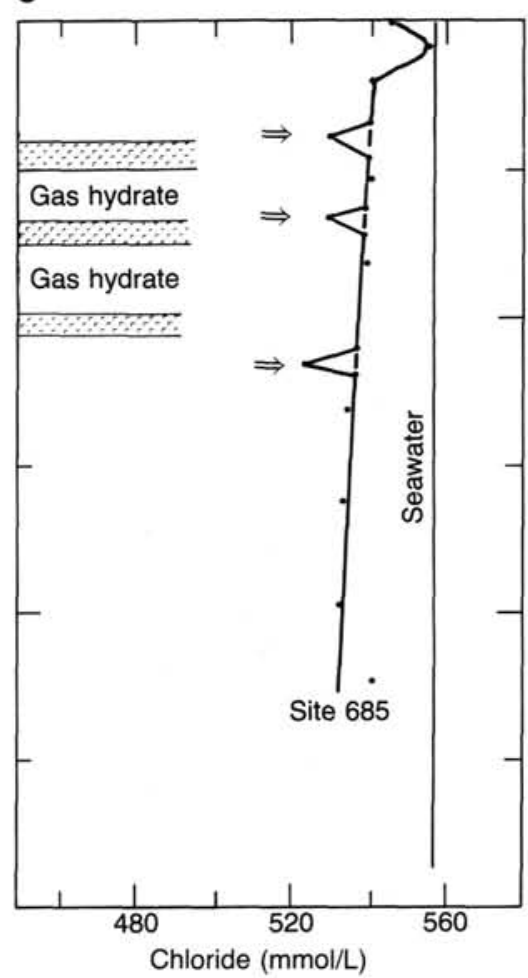

Figure 12. Dissolved chloride in pore waters of midslope sediments (Sites $682,683,685$, and 688 ); the anomaly pattern relative to normal seawater chloride results from several simultaneous processes: A) slight excess chloride (striped pattern) perhaps reflects salt exclusion during gas-hydrate formation; B) negative chloride spikes (small arrows) are thought to be sampling artifacts from dissociation of methane hydrate during core recovery; C) large chloride excursions in deep sections (open arrows) perhaps indicate flow of low chloride fluids; BSR = depth of bottom-simulating reflector. 


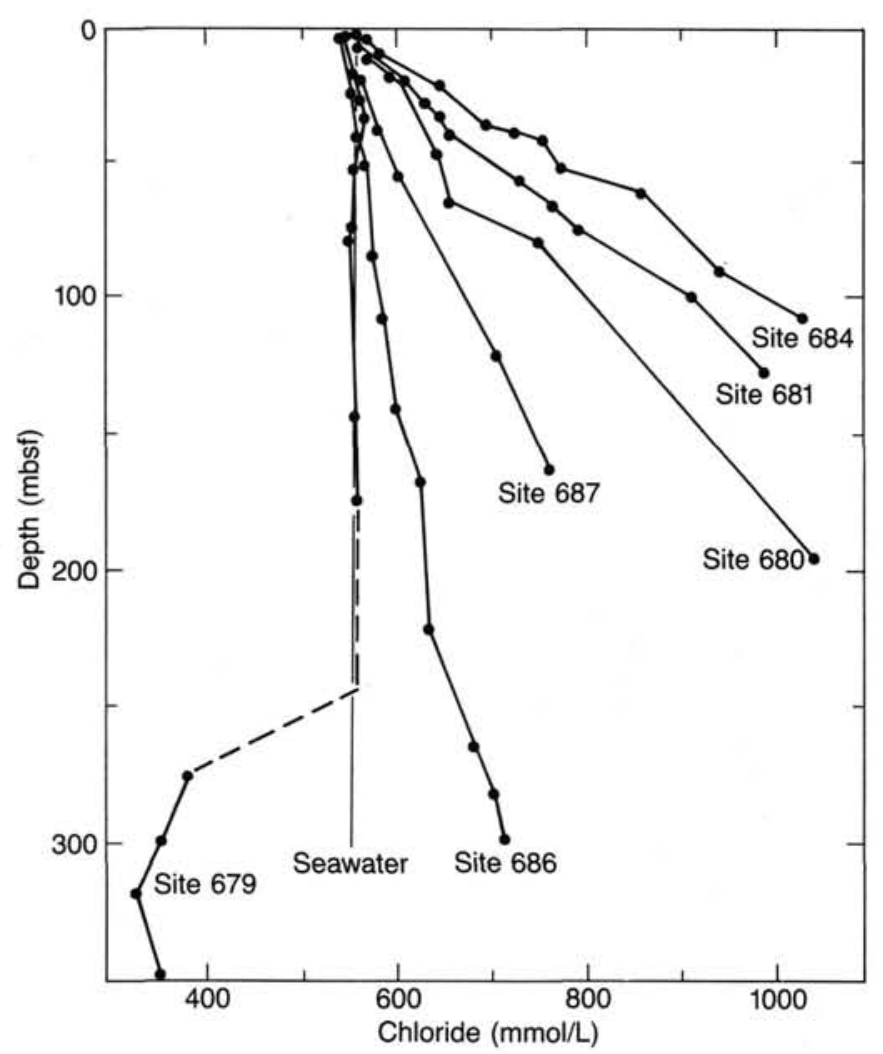

Figure 13. Interstitial chloride of pore waters of the Peru shelf sediments. A subsurface brine is evident from the drastically elevated chloride contents at all sites except Site 679. Pore fluids at Site 679 show small initial increases in dissolved chloride from an influx of subsurface brine; however, a much stronger effect of freshening at depth exists. The change in gradient at Site 679 coincides with a pronounced unconformity. Broken line indicates interval of no sample recovery.

Superimposed on the regional subsidence is a local variation in the tectonic history. Although the margin along both transects experienced the same subduction history (at different times), parts of each transect display different vertical tectonic movement (Fig. 15). Subduction of the Nazca Ridge corresponds in time to a change from tectonic erosion to accretion at the front of the margin. However, in the middle and upper-slope areas, the Trujillo Basin and the slope along the northern transect remained at about the same depth at a time when the Lima Basin and the slope along the southern transect recorded uplift and subsidence (Fig. 16). This difference was attributed to the subduction of Mendana Ridge (Thornburg, 1985). Alternatively, if the Nazca Ridge had different topographic features when subducted in the north than when subducted in the south, it may have resulted in different subcrustal tectonic processes in each of the areas, even though this is unlikely because the subducted and unsubducted parts of the ridge are thought to have had a similar topography (Cande, 1985). It has also been suggested that the configuration of the Benioff Zone changed at about 9 $\mathrm{Ma}$ (Ocola, 1983). Such a change might enhance a change in the subcrustal tectonic processes beneath the forearc basin. This problem of the differential subsidence of adjacent forearc basins also applies to the unique tectonic history of the Pisco Basin, located on- and offshore just south of Lima.

Normal faults are common on the upper slope and locally in the midslope area. This extended deformation is probably driven by downslope gravity forces (von Huene et al., 1985). Horizontal compressional deformation is restricted to the lower slope. At the scale of the cores, tectonic structures with a pervasively

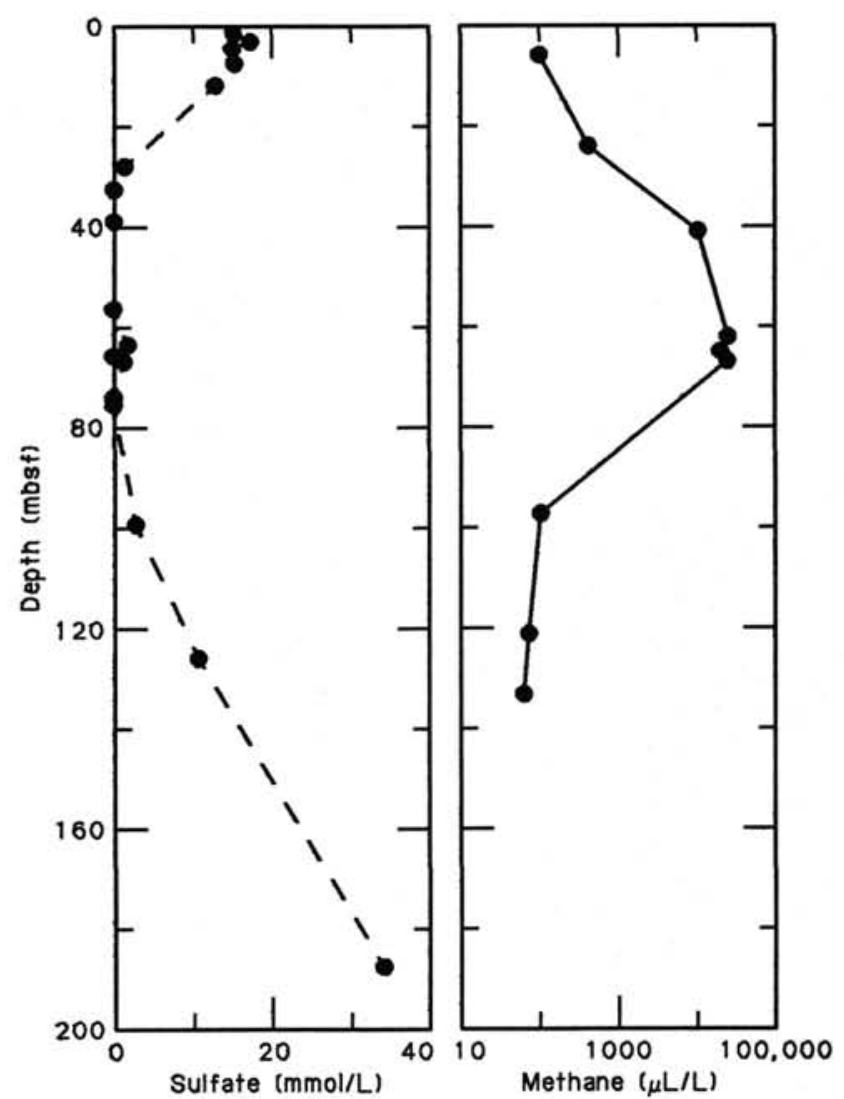

Figure 14. Dissolved sulfate and methane at Site 681. A zone of microbial sulfate reduction is followed by a zone of methanogenesis after complete sulfate exhaustion. The deepest part corresponds to a zone of renewed sulfate reduction caused by replenishment of sulfate from intrusion of the subsurface brine.

compressional fabric parallel to bedding were observed only at Site 685 . But even at Site 685 , only $12 \mathrm{~km}$ from the trench axis, the upper $80 \mathrm{~m}$ of Quaternary slope sediment had no compressional structure. This restriction of the zone of active compressional deformation can be explained by overpressured pore fluids and low-strength sediment mass. The seismic records show considerable subducted sediment, some of which is trench sediment. The upper part of the trench sediment sequence consists of turbidites and hemipelagic sediment (Prince and Kulm, 1975) probably having high porosities such as those found in the slope sediment during Leg 112. Considerable physical evidence of overpressured fluids and the free migration of fluids through fracture systems could be seen in the cores from all sites, particularly where the oxygen-minimum zone prevented the disturbance of sedimentary structures by bioturbation. The finely laminated sediment in these environments showed abundant waterescape structures and microfractures that appear to serve as conduits for fluids even in the impermeable mudstones.

\section{REFERENCES}

Baker, P. A., and Burns, S. J., 1985. Occurrence and formation of dolomite in organic-rich continental margin sediments. AAPG Bull., 69: 1917-1930.

Baker, P. A., and Kastner, M., 1981. Constraints on the formation of sedimentary dolomites. Science, 213:214-216.

Berner, R. A., 1978. Sulfate reduction and the rate of deposition of marine sediments. Earth Planet. Sci. Lett., 37: 492-498.

Bourgois, J., Pautot, G., Bandy, W., Boinet, T., Chotin, P., Huchon, P., Lepinay, B., Monge, F., Monlau, J., Pelletier, B., Sosson, M., and von Huene, R., 1986. Tectonic regime of the Andean convergent 
margin off Peru (SEAPERC cruise of R/V Jean Charcot, July 1986). Can. Roy. Acad. Sci. Paris, 1599-1604.

Cande, S. C., 1985. Nazca-South American Plate interactions since 50 my b.P. to Present. In Hussong, D. M., Dang, S. P., Kulm, L. D., Couch, R. W., and Hilde, T.W.C. (Eds.), Atlas of the Ocean Margin Program, Peru Continental Margin, Region VI: Woods Hole (Marine Science International), 14.

Claypool, G. E., and Kaplan, I. R., 1974. The origin and distribution of methane in marine sediments. In Kaplan, I. R. (Ed.), Natural Gases in Marine Sediments: New York (Plenum Press), 99-140.

Hanshaw, B. B., and Coplen, T. B., 1973. Ultrafiltration by a compacted clay membrane. II. Sodium ion exclusion at various ionic strengths. Geochim. Cosmochim. Acta, 37:2311.

Haq, B. U., Hardenbol, J., and Vail, P. R., 1987. Chronology of fluctuating sea levels since the Triassic ( 250 million years ago to present). Science, 235:1150-1167.

Hesse, R., and Harrison, W. E., 1981. Gas hydrates (clathrates) causing pore water freshening and oxygen isotope fractionation in deep-water sedimentary sections of terrigenous continental margins. Earth Planet. Sci. Lett., 55:453-462.

Hussong, D. M., and Wipperman, L. K., 1981. Vertical movement and tectonic erosion of the continental wall of the Peru-Chile Trench near $11^{\circ} 30^{\prime}$ S latitude. In Kulm, L. D., Dymond, J., Dasch, E. J., and Hussong, D. M. (Eds.), Nazca Plate: Crustal Formation and Andean Convergence. Geol. Soc. Am. Mem., 154:504-524.

Hussong, D. M., Dang, S. P., Kulm, L. D., Couch, R. W., and Hilde, T.W.C. (Eds.), 1985a. Atlas of the Ocean Margin Program, Peru Continental Margin, Region VI: Woods Hole (Marine Science International).

1985b. Peru Margin Drilling Proposal. Unpublished Report, JOIDES/ODP Site Survey Data Bank.

Imbrie, J., Hays, J. D., Martinson, D. G., McIntyre, A., Mix, A. C., Morley, J. J., Pisias, N. G., Prell, W. L., and Shackleton, N. J., 1984. The orbital theory of Pleistocene climate: support from a revised chronology of the marine delta ${ }^{18} \mathrm{O}$ record. In Berger, A., Imbrie, J., Hays, J., Kukla, G., and Salzman, B. (Eds.), Milankovitch and Climate, Part 1: Dordrecht (Reidel), 269-305.

Kirschvink, J. L., and Chang, S. R., 1984. Ultrafine-grained magnetite in deep-sea sediments: possible bacterial magnetofossils. Geology, 12:559-562.

Kulm, L. D., Dymond, J., Dasch, E. J., and Hussong, D. M. (Eds.), 1981. Nazca Plate: Crustal Formation and Andean Convergence. Geol. Soc. Am. Mem., 154.

Kulm, L. D., Suess, E., and Thornburg, T. M., 1984. Dolomites in the organic-rich muds of the Peru fore-arc basins: Analogue to the Monterey Formation. In Garrison, R. E., Kastner, M., and Zenger, D. (Eds.), Dolomites in the Monterey Formation and other Organicrich Units. Soc. Econ. Paleontol. Min. Spec. Publ., 41:29-48.

Kulm, L. D., Thornburg, T. M., and Dang, S., 1985. Drill hole stratigraphy, dredge lithologies, and sample locations. In Hussong, D. M., Dang, S. P., Kulm, L. D., Couch, R. W., and Hilde, T.W.C. (Eds.), Atlas of the Ocean Margin Program, Peru Continental Margin, Region VI: Woods Hole (Marine Science International), 18.

Kulm, L. D., Miller, J., and von Huene, R., 1987. The Peru Continental Margin Record Section 2. In von Huene, R. (Ed.), Seismic Images of Modern Convergent Margins: Tulsa (AAPG Studies in Geology Series), 26.

Kvenvolden, K. A., and McMenamin, M. A., 1980. Hydrates of Natural Gas: a Review of Their Geologic Occurrence: U.S. Geol. Surv. Circ., 825 .

Marine, I. W., and Fritz, S. J., 1981. Osmatic model to explain anomalous hydraulic heads. Water Pressure Res., 17:73.

Miller, J., Hussong, D., and von Huene, R., 1986. Peru continental margin, record section 3. In von Huene, R. (Ed.), Seismic Images of Modern Convergent Margin Tectonics Structure: Tulsa (AAPG Studies in Geology Series), 26:32-33.

Moore, J. C., and Mascle, A. 1987. Expulsion of fluids from a depth along a subduction-zone decollement horizon. Nature, 326:785-788.

Moore, J. C., Mascle, A., et al., 1988. Proc. ODP, Init. Repts., 110: College Station, TX (Ocean Drilling Program).
Nur, A., and Ben-Avraham, Z., 1981. Volcanic gaps and the consumption of aseismic ridges in South America. In Kulm, L. D., Dymond, J., Dasch, E. J., and Hussong, D. M. (Eds.), 1981. Nazca Plate: Crustal Formation and Andean Convergence. Geol. Soc. Am. Mem., 154:729-740.

Ocala, L., 1983. Geophysical data and Nazca-South American subduction zone kinematics: Peru-Chile segment. In Geodynamics of the Eastern Pacific Regions, Caribbean, and Scotia Arcs: Washington (Am. Geophys. Union, Geodynamics Ser.), 9:95-112.

Pisias, N. G., Martinson, D. G., Moore, T. C., Shackleton, N. J., Prell, W., Hays, J., and Boden, G., 1984. High resolution stratigraphic correlation of benthic oxygen isotopic records spanning the last 300,000 years. Mar. Geol., 56:119-136.

Prince, R. A., and Kulm, L. D., 1975. Crustal rupture and initiation of imbricate thrusting in the Peru-Chile Trench. Geol. Soc. Am. Bull., 86:1639-1653.

Prince, R. A., Schweller, W. J., Coulbourn, W. T., Shepherd, G. L., Ness, G. E., and Masias, A., 1980. Bathymetry of the Peru-Chile continental margin and trench. Geol. Soc. Am. Map Chart Ser., MC-34.

Reimers, C. E., and Suess, E., 1983. Spatial and temporal patterns of organic matter accumulation on the Peru continental margin. In Suess, E., and Thiede, J. (Eds.), Coastal Upwelling, Part B: Sedimentary Records of Ancient Coastal Upwelling: New York (Plenum Press), 311-345.

Rutland, R.W.R., 1971. Andean orogeny and ocean floor spreading. Nature, 233:252-255.

Scholl, D., Christensen, M. N., von Huene, R., and Marlowe, M., 1970. Peru-Chile Trench sediments and sea-floor spreading. Geol. Soc. Am. Bull., 81:1339-1360.

Suess, E., Kulm, L. D., and Killingley, J. S., 1987. Coastal upwelling and a history of organic-rich mudstone deposition off Peru. In Brooks, J., and Fleet, A. J. (Eds.), Marine Petroleum Source Rocks. Geol. Soc. London Spec. Publ., 24:181-197.

Suess, E., and Thiede, J., 1983. Responses of the sedimentary regime to coastal upwelling. In Suess, E., and Thiede, J. (Eds.), Coastal Upwelling: Its Sediment Record, Part A: New York (Plenum Press).

Thiede, J., 1983. Skeletal plankton and nekton in upwelling water masses off northwestern South America and Northwest Africa. In Suess, E., and Thiede, J. (Eds.), Coastal Upwelling: Its Sediment Record, Part A: New York (Plenum Press), 183-207.

Thiede, J., and Suess, E. (Eds.), 1983. Coastal Upwelling: Its Sediment Record, Vol I: New York (Plenum Press).

Thornburg, T. M., 1985. Seismic stratigraphy of Peru forearc basins. In Hussong, D. M., Dang, S. P., Kulm, L. D., Couch, R. W., and Hilde, T.W.C. (Eds.), Atlas of the Ocean Margin Program, Peru Continental Margin, Region VI. Woods Hole (Marine Science International), 16 .

Thornburg, T. M., and Kulm, L. D., 1981. Sedimentary basins of the Peru continental margin: structure, stratigraphy, and Cenozoic tectonics from $6^{\circ} \mathrm{S}$ to $16^{\circ} \mathrm{S}$ latitude. In Kulm, L. D., Dymond, J., Dasch, E. J., and Hussong, D. M. (Eds.), Nazca Plate: Crustal Formation and Andean Convergence. Geol. Soc. Am. Mem., 154:469508.

von Dobeneck, T., Petersen, N., and Vali, H., 1987. Bakterielle Magnetofossilien. Geowiss. Zeit., 1:27-35.

von Huene, R., and Lee, H., 1982. The possible significance of pore fluid pressures in subduction zones. Studies in continental margin geology. AAPG Mem., 37:781-789.

von Huene, R., Kulm, L. D., and Miller, J., 1985. Structure of the frontal part of the Andean convergent margin. J. Geophys. Res., 90: 5429-5442.

Wefer, G., Dunbar, P. B., and Suess, E., 1983. Stable isotopes of foraminifers off Peru recording high fertility and changes in upwelling history. In Thiede, J., and Suess, E. (Eds.), Coastal Upwelling: Its Sediment Record, Part B: New York (Plenum Press), 295-308.

\section{Ms 112A-102}



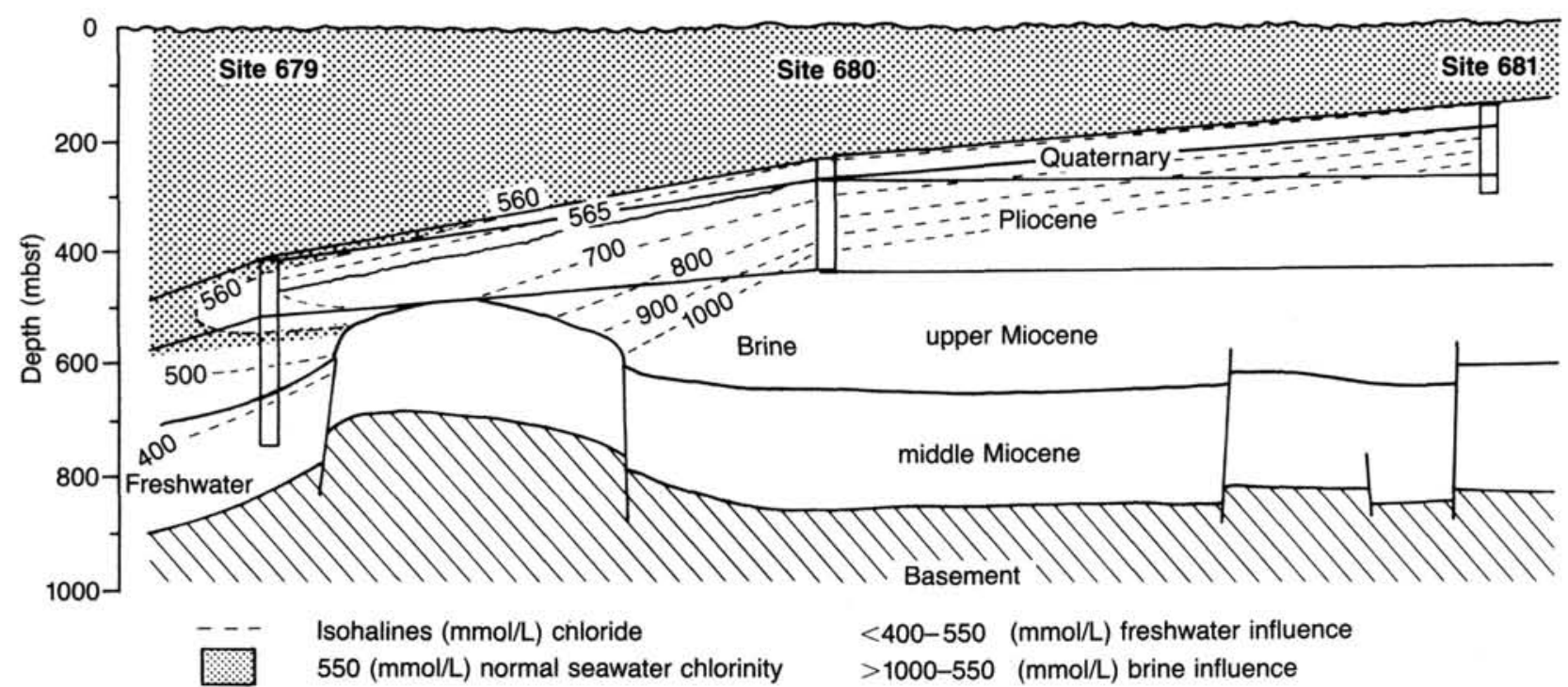

$$
\begin{aligned}
& <400-550 \quad(\mathrm{mmol} / \mathrm{L}) \text { freshwater influence } \\
& >1000-550 \quad(\mathrm{mmol} / \mathrm{L}) \text { brine influence }
\end{aligned}
$$

Figure 15. Generalized stratigraphic and structural relationship of shelf sediments drilled along the southern transect (Sites 679, 680, and $681)$. Isolines of dissolved chloride $(\mathrm{mmol} / \mathrm{L})$ in interstitial waters delineate the extent and maximum chloride contents $(>1000 \mathrm{mmol} / \mathrm{L})$ of the subsurface brine and the zone of freshwater influence $(<550 \mathrm{mmol} / \mathrm{L})$.

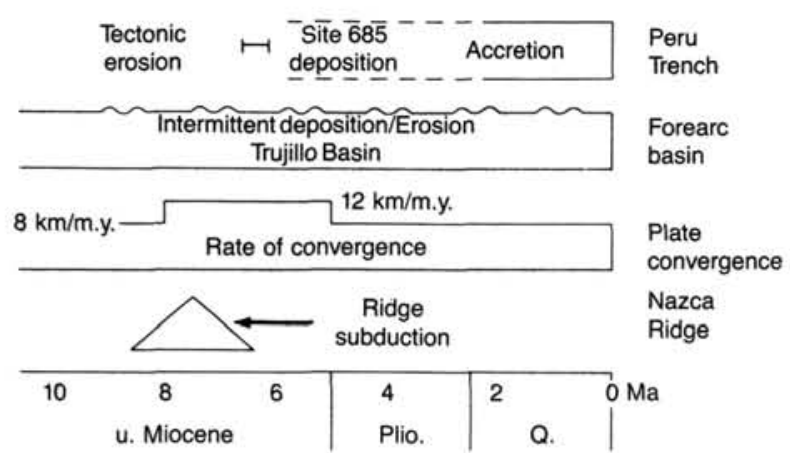

Plate and Margin Histories - $9^{\circ} \mathrm{S}$

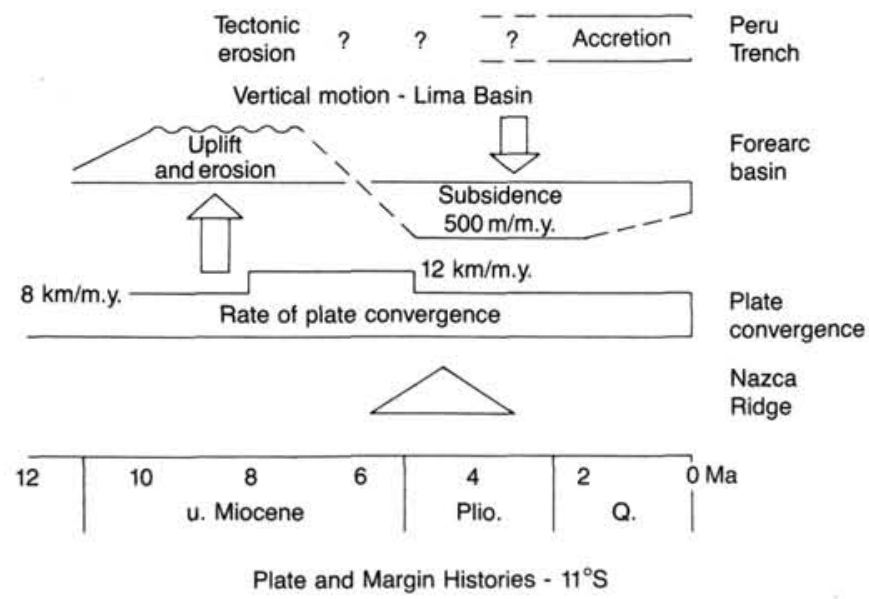

Figure 16. Tectonic history along the Peru Continental Margin in the northern and southern transects, compared with history of subduction. Indicated onset and completion of Nazca Ridge subduction is when the $3000-\mathrm{m}$ isobath entered the trench and when it was subducted, assuming recent trench position (Cande, 1985). The change from tectonic erosion to accretion is coeval with the subduction of the Nazca Ridge. However, Trujillo and Lima basins respond differently to ridge subduction, and their dynamics appear moderated by other tectonic processes. 